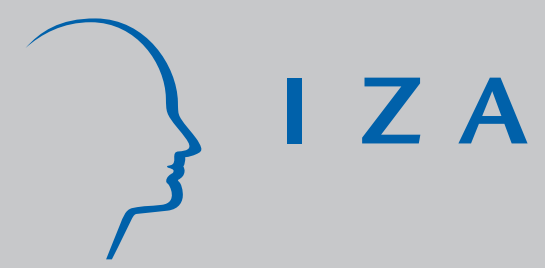

IZA DP No. 8241

Yuan and Roubles: Comparing Wage Determination in Urban China and Russia at the Beginning of the New Millennium

Björn Gustafsson

Li Shi

Ludmila Nivorozhkina

Haiyuan Wan

June 2014 


\title{
Yuan and Roubles: Comparing Wage Determination in Urban China and Russia at the Beginning of the New Millennium
}

\author{
Björn Gustafsson \\ University of Gothenburg and IZA \\ Li Shi \\ Beijing Normal University and IZA \\ Ludmila Nivorozhkina \\ Rostov State Economic University \\ Haiyuan Wan \\ National Development and Reform Commission, China
}

Discussion Paper No. 8241

June 2014

IZA

P.O. Box 7240

53072 Bonn

Germany

Phone: +49-228-3894-0

Fax: +49-228-3894-180

E-mail: iza@iza.org

\begin{abstract}
Any opinions expressed here are those of the author(s) and not those of IZA. Research published in this series may include views on policy, but the institute itself takes no institutional policy positions. The IZA research network is committed to the IZA Guiding Principles of Research Integrity.

The Institute for the Study of Labor (IZA) in Bonn is a local and virtual international research center and a place of communication between science, politics and business. IZA is an independent nonprofit organization supported by Deutsche Post Foundation. The center is associated with the University of Bonn and offers a stimulating research environment through its international network, workshops and conferences, data service, project support, research visits and doctoral program. IZA engages in (i) original and internationally competitive research in all fields of labor economics, (ii) development of policy concepts, and (iii) dissemination of research results and concepts to the interested public.
\end{abstract}

IZA Discussion Papers often represent preliminary work and are circulated to encourage discussion. Citation of such a paper should account for its provisional character. A revised version may be available directly from the author. 


\title{
ABSTRACT
}

\section{Yuan and Roubles: Comparing Wage Determination in Urban China and Russia at the Beginning of the New Millennium*}

\begin{abstract}
Earnings inequality and earnings determination in urban China 2002 and Russia 2003 are compared using samples covering large parts of the two countries. The results from estimated earnings functions are put in perspective of the outcome from a similar comparison made at the end of the 1980s. We confirm that earnings inequality has increased rapidly in both countries and is found to be similar across countries. As at the end of the 1980s, the gender wage gap is larger in Russia where earnings reach a maximum at a lower age than in China. The association between education and income in China has increased to become stronger than in Russia. The earnings penalty of being employed in the public service sector in Russia has increased while the publically employed in China enjoy a positive payoff of limited magnitude.
\end{abstract}

JEL Classification: J16, J31, J45, P23

Keywords: $\quad$ wages, wage inequality, gender wage gap, China, Russia

Corresponding author:

Björn Gustafsson

Department of Social Work

University of Gothenburg

P.O. Box 720

SE 40530 Göteborg

Sweden

E-mail: Bjorn.Gustafsson@socwork.gu.se

\footnotetext{
Forthcoming in China Economic Review. Revised version of paper presented at the conference China as a leader in the world economy: implications for the political economy, CERDI-IDREC, University of Auvergne, Clermont-Ferrand, France, 24-25 October, 2013.
} 


\section{Introduction}

For many years, the systems of employment and remuneration in the urban regions of China and Russia were broadly the same. Workers were allocated to jobs and wages were set using centrally determined wage scales. It has been shown that at the end of the 1980s, wage inequality was similar in the two countries. However, despite the common origins in systems of wage determination, the relationship between personal characteristics and earnings was considerably different. Earnings increased with age up to the general retirement age in China, but not in Russia. By contrast, the relationship between education and wages was much stronger in Russia, and the gender wage gap was substantially larger (see Gustafsson et al, 2001).

Market principles have increasingly played a much larger role for allocation and remuneration of workers in China and in Russia. The countries also share the fact that the state is no longer the principal employer. The transformation took place during years when the Chinese economy grew rather rapidly, as did real wages. By contrast, Russia experienced negative economic growth, falling real wages and large problems funding the public sector throughout the 1990s. How do wage inequality and wage determination in urban China and urban Russia compare at the beginning of the new millennium? What changes can be found since the end of the 1980s? In which aspects have cross-country differences existing at the end of the 1980s prevailed? These are the research questions for this paper. We compare wage inequality and wage determination in the two countries at a point in time when the wage-setting mechanism had changed in both countries. However, the supply and demand of workers of varying qualifications developed differently in the two countries.

China and Russia are the two largest countries that have experienced a transition from a planned economy to a market economy and there are studies on wage inequality and wage determination in each of the countries. Cross-country comparisons have the potential to generate new questions and insights. They can ask diverse questions and cover many countries or concentrate on just two countries. The latter alternative allows for asking deeper questions. Our research questions, to our knowledge, have attracted very little attention in the literature. The only similar study we are aware of is Carnoy et al (2012) who report rapidly increased strength in the association between education and earnings in China and a more moderate increase in Russia since market reforms were introduced in the two countries. ${ }^{1}$ However, that particular study did not evaluate changes in wage inequality, gender wage gaps and earnings gaps between public service sector and other employed individuals as we do. Our analysis uses data from the China Household Income Project (CHIP) for 2002 and for Russia, a large sample covering the entire country (NOBUS) for 2003. We estimate earnings functions for mean earnings but also at different positions of the earnings distribution.

Our findings show not only large changes but also continuity. We confirm that wage inequality increased across time in both countries and was of the same magnitude in both countries. A major change which is consistent with what is reported in the literature is that the association between education and earnings increased rapidly in China and became even larger than the association in Russia. Furthermore, we report that the penalty of being employed in the public service sector in Russia in 2003 was larger than according to data collected during the Soviet period. In contrast, in urban China in 2002 there was a small positive earnings premium of being employed in the public sector. In other aspects, earnings

\footnotetext{
${ }^{1}$ Carnoy et al (2012) worked with other data than ours and also studied Brazil and India.
} 
determination on the whole remained unchanged in both countries from the end of the 1980s to the beginning of the new millennium. Earnings reached a maximum at an earlier age in urban Russia than in urban China. The gender wage gap continued to be larger in Russia particularly at the top of the earnings distribution.

The rest of the paper is laid out as follows: In the next section we provide the context for the comparison. The data we use is described in Section 3 and our samples in Section 4. In Section 5 we describe earnings in the two samples. Section 6 contains the results from the earnings function analysis. Finally, Section 7 summarizes the study.

\section{Context}

During the planning époque, labour was administratively allocated in China and Russia, and wages were set using wage scales. After having finished education the typical worker was assigned his or her first job, which often turned out to be the last as labour turnover was very low. Almost all workers were employed in state or collective enterprises, alternatively in public institutions. Public policy measures contributed to make and keep the number of private firms and the number of self-employed rather low. Most people in work active ages, men and women alike, worked for pay. Unemployment was not an officially recognized problem. For quite some time now, this description has been relegated to history.

China experienced rapid economic growth; coupled to this, a rapid increase in workers' real wages occurred after the first reform steps were taken at the beginning of the 1980s. State involvement in the Chinese economy decreased gradually for many years. Unlike Russia, rapid economic growth generated growing resources to remunerate workers in public service institutions. One early reform step was taken in 1984 when college graduates were given the opportunity to find jobs by themselves; this became the only alternative in 1993. During the second half of the 1990s, changes towards market allocation became radical. The system of lifelong employment was terminated. Parallel to this, State Owned Enterprises (SOEs) were put under pressure to be profitable. In consequence, many workers became redundant; some became unemployed while others left the labour force entirely.

From 1995 to 2002, the number of workers employed in SOEs and collective firms decreased from 141 million to 80 million in China, a reduction of 61 million persons (NBS, various years). During this period, job losses in SOEs were only partly counteracted by growing employment in the private sector and in self-employment. Employment problems were more severe for unskilled workers than for skilled workers, female workers were more affected than male workers, and some locations were harder hit than others (Gustafsson and Ding, 2013).

Vast industrial expansion coupled with increased investments generating demand for relatively skilled workers are generally believed to have played a major role in China's rapid economic expansion. There have also been changes in labour supply. Since reform began, urban China has seen rapid inflows of unskilled migrants to the cities. The typical migrant is a young unskilled worker who does not have an urban hukou (residence permit). Some migrate temporarily while others tend to stay for life. Typically the rural migrant finds a job and works long hours. The rapid growth in the number of rural migrants looking for and finding a job in urban China, according to many observers, has put forceful downward pressure on wages for unskilled urban residents. Increased demand for skilled workers, increased supply of low-qualified workers together with new wage setting mechanisms are 
most likely the circumstances behind several authors reporting increased positive association between education and earnings in urban China for a substantial number of years (Zhuo, 2000, Fleisher and Wang, 2005, Appleton et al 2005, Zhang et al 2005, Cai et al 2008, Knight and Song, 2008). However, there is now evidence that the increase in the strength of the association between education and earnings in China came to a halt a few years after 2002, the year studied here (Appleton et al 2012, Yang et al 2013, Li and Song, 2013). The background to this is the forceful expansion of higher education. For a long time, the number of students in China enrolled in higher education was low. For example, not more than 0.7 million persons were enrolled in higher institutions in 1988. In 1999 state policy initiated a very rapid expansion of higher education, and as a consequence, no fewer than 3.2 million students were enrolled in 2002. The increase continued and in 2007, for example, the number of students had increased to 6.6 million. Earnings inequality increased as well after reforms were begun, and also after our data was collected (Meng, 2012 and Meng et al 2013).

The Russian story of transition towards market allocation is different from the Chinese in many respects. It started later, during the years 1992 to 1994, and it was abrupt - with mass privatization of economic activities and the introduction of private property rights. In contrast to the situation in China, steps towards a western-style political democracy were taken but institutions were eroded. For many years after the Soviet Union was dissolved, Russia experienced negative economic growth and workers' real wages fell dramatically (see Popov, 2013 and Gimpelson and Kapeliushnikov 2013). Unlike China, GDP rapidly decreased and eroding tax bases led to large problems in funding public services and workers. The topic of underpaid workers in schools, hospitals and other parts of the public sector has come to loom large in discussions on economic and social policies in Russia (Gimpelson and Lukyanova, 2009). Similar to the situation in China, unemployment surfaced in Russia during the late 1990s and many workers left the labour force. The downward spiral of the Russian labour market came to a halt during the beginning of the new millennium, which is approximately when the data analyzed here was collected; see Entov and Lugovoy (2013).

Similar to the situation in China, new principles for wage setting were introduced in reform Russia. Wage inequality increased rapidly at the start of the transition and continued until the end of the old millennium, However, according to Lukyanova (2006), there was a rapid decrease in earnings inequality from 2001 to 2002 (just before the year the data we are analyzing here was collected) which brought earnings inequality back to a level similar to what was observed in the first half of the 1990s.

In Russia during the Soviet era the number of students in secondary vocational schools and institutions of higher education were regulated by the Ministry of Education. Access to education was on a competitive basis and was free of charge. Moreover, students who had high marks in the studied subjects received small scholarships. Since the beginning of the 1990s, institutions of higher education have the right to teach a certain number of students on a commercial basis and there are universities that receive and train students on a fully commercial basis. This expansion, which started some years earlier than China's, lowered the employment problems among young adults during a period of deep economic crisis and led to an increase in the number of graduates in fields that are in demand in emerging market economies, such as economists and lawyers. The salaries of teachers in public higher education institutions fell rapidly, but the staff often had opportunities for earning additional income at the newly created commercial institutions of higher education. This process was also characterized by lowered requirements for students entering higher education. Teaching quality declined in higher education institutions and corruption appeared. According to 
official statistics, the number of students in all educational institutions of higher education for the academic year 1980-1981 was 3.0 million; for the academic year 1990-1991, 2.8 million. Given the lack of expansion of higher education and that earnings came to be more marketdetermined it is not surprising that association between education and earnings became stronger during the first half of the 1990s (Gorodnichenko and Sabirianova Peter, 2005). However the number of students increased to as many as 4.7 million for the academic year 2000-2001 and to 6.5 million for the academic year 2011-2012. The percentage of students studying at private (commercial) institutions of higher education was 10 per cent in 20002001 and 16 percent in 2011-2012. ${ }^{2}$

As the Soviet Union before it was dissolved had already become an urbanized society, reform in Russia during the 1990s was not the same as reform in China; Russia did not experience a rapidly increased supply of unskilled rural workers, a fact that taken separately must have pushed the association between education and earnings to become stronger. However, as the economy started to grow in the 2000s, the demand for unskilled labor increased and Russia has experienced a substantial inflow of workers from territories that had changed status from being republics in the Soviet Union to being independent countries. Many such migrants do not have a work permit.

\section{Data}

The Chinese data comes from the China Household Income Project (CHIP) and is the outcome of collaboration between researchers who designed questionnaires and the National Bureau of Statistics which was responsible for the sampling and fieldwork (see Li et al 2008). The target population is persons with an urban hukou living in areas that by administrative definitions are considered urban. From this it follows that the sample does not cover people living in urban areas who lack an urban hukou. This property is shared by most other studies on wages and wage inequality in urban China that we are aware of. The sample was obtained by a multi-stage procedure in which the province level units Beijing, Shanxi, Liaoning, Jiangsu, Anhui, Henan, Hubei, Guangdong, Chongqing, Sichuan, Yunnan and Gansu were selected. A sample of 6835 households living in 77 cities was obtained from larger samples regularly used by NBS to produce official statistics for China. This sample was derived in a manner very similar to the sample for 1988 used to study earnings in China in comparison to earnings in Russia as reported in Gustafsson et al (2001). From this it follows that results for China from this study are highly comparable with those for 1988 reported in Gustafsson et al (2001).

The Russian data comes from the National Survey of Household Welfare and Participation in Social Programs, also known as NOBUS (from the Russian acronym). It was administered in the second quarter of 2003 by the Federal Service of State Statistics (Rosstat) with the technical assistance of the World Bank. The survey uses a random sample of 44529 households and 107695 individuals which was created using a multi-stage stratification, i.e., subsequent random selection with a two-phase selection. First, seven types of settlements (strata) were defined mainly by population size of the location and then sampled. At a later stage, households were selected from addresses. To make the Russian sample more comparable with the Chinese sample that refers to urban areas, we deleted respondents who

\footnotetext{
${ }^{2}$ Source: The official website of Federal State Statistics Service http://www.gks.ru/free_doc/new_site/population/obraz/vp-obr1.htm. See also Kaganovich (2013).
} 
lived in settlements with a population smaller than 20000 inhabitants. The Russian sample used in Gustafsson et al (2001) was the best among available alternatives for this country during the Soviet period. However, it refers to one city only; Taganrog, a middle-sized industrial town in southern Russia. ${ }^{3}$ In consequence, comparability across years for urban Russia is not as high as for urban China. Note that due to this fact, the cross-country comparison reported here is higher than in the study investigating earnings at the end of the 1980s.

The population under study for the earnings analysis in this paper is defined as all individuals with positive earnings (wages or self-employed income) without any age restrictions. We define earnings net of income taxes as in the Russian survey; respondents were asked for the amount of earnings net of taxes. In order to harmonize definitions across the two datasets used here, we have imputed income taxes in the Chinese data based on the tax scale applicable for China for 2002. It turns out that this imputation affected 43 percent of the observations as the personal tax exemption is actually slightly higher than median earnings in our sample.

China and Russia cover large territories and consumer prices are known to vary widely throughout. To correct for regional price differences we use consumer price indices in many of the analyses and show results for household income adjusted for the presence of regional price differences. The Chinese price index is an updated version of the index developed by Brandt and Holz (2006). For Russia we apply the subsistence minimum amounts which were introduced in 1992 and have become the standard definition of poverty in Russia. The subsistence minimum is sufficient for food and everyday necessities (housing, fuel, energy and communal services) and varies across Russia's administrative divisions consisting of 83 subjects (subyekly) in order to take account of price variations across the country. It constitutes the perhaps most used regional price index for Russia. We apply the version in effect for the period April to June 2003. The subsistence minimum is higher in northeast Russia as well as in the capital region.

\section{The samples}

\section{/ Figure 1 about here/}

Based on our data we define employment rates for each single age from 16 to 83 for each gender in the two countries. Figure 1 shows the employment rates for persons aged 16 to 30 in China and Russia. Among young adults, particularly for males, we report higher employment rates in Russia. The comparably low employment rates among young adults in urban China are a new phenomenon and are consistent with the expansion of education that has taken place. For example, using the same data Gustafsson and Ding (2013) show that while 95 percent of males aged 18 to 29 were employed in 1988, the corresponding

\footnotetext{
${ }^{3}$ When originally selected by a group of social scientists for a sequence of surveys in the 1960s, Taganrog was considered a typical middle-sized Russian industrial town in terms of average income, pattern of employment, housing conditions, and family size. Furthermore, the wage-setting mechanism in the Soviet Union was rather uniform across the country, see for example Katz (2001). However, incomes in Taganrog grew comparatively slowly during the 1980s, which might have been a result of the dominance of heavy industry in the city.
} 
proportion decreased to 68 percent in 1995 and to 49 percent in 2002 as well as 2007 . Parallel to this, the proportion of persons involved in studies increased. The employment rate among young women also declined in Russia as a larger proportion of a birth cohort became involved in higher education. ${ }^{4}$ Between ages 23 and 30, differences between urban China and urban Russia were small as almost 90 percent of males were employed and the proportion was not much lower for females in each of the two countries.

/Figure 2 about here/

For ages over 30, the employment rate among females in urban China was considerably lower than for the three other categories, see Figure 2. After age 50 only a minority of females in urban China were employed, while this situation occurred among the other three categories closer to age 60. One background for the low employment rate among females in urban China over age 50 is that females in manual jobs typically retire at age 50. In addition, the downsizing of State Owned Enterprises had in 2002 led to many job losses among middle-aged and older females as they left the workforce or became unemployed. ${ }^{5}$ Common to both countries is that only a small proportion of persons over age 60 were employed and thereby studied in this paper. In Russia, women typically retire at age 55 and men at age 60 . Some categories of workers such as teachers and health workers can retire at age 50. However, persons receiving pensions are allowed to work after retirement and a significant portion of the population chooses to do so. Actually more than a quarter of people in Russia who qualify for retirement do not leave employment and among teachers and health workers the proportion is as high as $77 \% .^{6}$

\section{/Table 1 about here/}

Table 1 describes the two samples by characteristics. It also shows how earnings vary by these characteristics, which will be discussed in the next section of the paper. Several comments can be made based on the contents of the table and comparisons made to similar information from samples referring to the end of the 1980s (as reported in Gustafsson et al, 2001). Starting with the gender composition of the samples we find that while females are in a slight majority in the Russian sample, the reverse is true in the Chinese. The latter should be seen from the perspective of the relatively low employment rate among females aged 50 and above discussed above. The median age of the two samples is similar, which for Russia means two years older than the Russian sample from the 1980s and not less than four years older for the Chinese sample compared to the sample for 1989.

Workers in the Russian sample have on average longer educations than their Chinese counterparts and in both samples the proportion with lower-middle-school or shorter educations has decreased since the end of the 1980s. Mirroring the latter, the proportion of

\footnotetext{
${ }^{4}$ The employment rate among females aged 16 - 20 went from 26 percent in 1992 (the first year when official statistics were published) to 18 percent in 2003. In contrast the employment rate among men of the same age stood at 19 percent in 1992 and 20 percent in 2003. Source: The official website of Federal State Statistics Service http://www.gks.ru/bgd/regl/b10_61/IssWWW.exe/Stg/01-01.htm

${ }^{5}$ However, later employment rates among older female workers in urban China increased. This is shown for 2007 in Gustafsson and Ding (2013).

${ }^{6}$ See Gurvich Evsej. Surcharge for age. [Electronic resource] http://ecpol.ru/index.php/2012-04-05-13-4431/2012-04-05 -13-45-10/86-nadbavka-za-vozrast, date accessed 25.01.2013).
} 
workers classified as manual laborers has decreased since the end of the 1980s while the reverse is true among the categories office worker and professionals. Turning to production sector we report that as many as 40 percent of the workers in the Chinese sample are employed in public services, while the corresponding percentage in the Russian sample is not higher than 26 percent. In each sample, one of four is employed in manufacturing. Russia has the higher proportion of workers in construction as well as in trade and services. The rather low proportion of workers in the construction sector in China should be understood from the fact that most construction work in urban China is carried out by migrant workers who are not included in the sample. We have information on ownership sector for both countries and similarities across the countries are relatively large. Most workers were employed in public firms according to responses from the workers; somewhat more than one-fourth were employed in privately-owned firms. In Table 1 we also break down the samples by size of the settlement in four categories and by seven regions in each of these vast countries.

\section{Earnings and earnings inequality}

We now turn to how earnings vary by breakdowns in the two samples as reported in Table 1 . Let us first compare numbers in the two columns showing mean earnings that are not corrected for as well as those corrected for regional price differences. We find that such adjustments have little effect on income estimates by breakdown by individual characteristics, but unsurprisingly more when it comes to spatial breakdowns. When adjusting for regional price differences, many spatial income differences are muted. Interestingly we see that while average nominal earnings in the far east are above the average for Russia, average earnings corrected for spatial price differences are under the average.

A first observation is that the gender wage gap in the two samples is surprisingly similar to that which was found in the samples from the end of the 1980s analyzed in Gustafsson et al (2001). Average female earnings are much lower in relation to average male earnings in Russia (66.0 percent in 2003, and 65.4 in the sample from the end of the 1980s) than in China (81.4 percent in 2002 and 82.4 percent in 1988). A second observation is that mean earnings reach a maximum at a lower age in Russia similar to the situation at the end of the 1980s. The maximum in Russia 2003 is reached at ages 36 to 45, while in China 2002 at ages 56 to 60.

A third observation is that the raw earnings premium for college and higher-educated workers compared to workers with lower-middle educations is largest in the Chinese sample from 2002, when it was 1.9 to 1 , as compared to 1.2 to 1 at the end of the $1980 \mathrm{~s}$; a substantial increase. The change in Russia was smaller (from 1:1.2 to 1:1.5). Not surprisingly, in both countries manual workers and office workers earn below average, while professionals as well as managers and officials earn above. Turning to the production sector we find the largest difference across countries in the relative earnings for workers employed in the public sector. Such workers were paid 12 percent above the average in China, but 16 percent below the average in Russia. As discussed in Section 2 this cross-country difference is consistent with the large funding problems the public sector in Russia has faced. Common to both countries, the rather small proportion of workers employed in (fully or mixed) foreign ownership earn more than other workers. In China workers in private firms earn somewhat less than average earnings.

/Table 2 about here/ 
In Table 2 we report Gini coefficients for earnings for urban China 2002 and urban Russia 2003 referring to all workers as well as to the large subset of workers aged 25 to 55 . As in Table 1 there are two alternative estimates. In one we have not adjusted for spatial differences in consumer prices and these are comparable with the estimates for the end of the 1980s that are documented in Gustafsson et al (2001) which are reproduced in the table. The other estimate is based on income adjusted for regional price differences. We report Gini coefficients computed for workers of both genders as well as for each gender separately.

There are large differences in Gini coefficients across time reported for both countries in Table 2. For example, the Gini for all workers of all ages in urban China rose from 0.252 in 1988 to 0.370 in 2002 when no regional price adjustments are made and to 0.356 when earnings are corrected for regional price differences. That correcting for regional price differences leads to a modest reduction in the Gini is also shown in other comparisons. The Gini for the Russian 2003 sample computed after correcting for regional price differences is 0.344 which is rather close to the corresponding estimate for China. The conclusion that earnings inequality in urban China 2002 is rather similar to earnings inequality in urban Russia 2003 also follows when restricting the sample by age and when comparing each gender. $^{7}$

\section{Earnings functions}

In order to better understand differences in earning determination between urban China 2002 and urban Russia 2003 we have estimated log earnings functions. We proceed in several steps. The first is to estimate models including gender, age, education and location as explanatory variables to show the big picture. The specification uses four dummies expressing levels of education, nine dummies for age, five dummies for region in China and six dummies for region in Russia as well as four dummy variables for city size. Two alternative dependent variables are used. They differ by whether earnings are deflated with the regional price index or not. The models are estimated by OLS. Variable definitions are provided in the Appendix and the results are shown in Table 3.

This type of specification has over the years been used in many contexts. The coefficients for the variable or variables measuring education can, under certain circumstances, be interpreted as the private rate of return to education (See Mincer, 1974). However, as is well-discussed in the literature, such estimated education coefficients run the risk of being a biased estimate of the "true" private rate of education; other potentially income-generating factors that might be correlated with education (for example ability) are not included in the estimated equation. The importance of such omitted income-generating factors might differ across countries and over time. From this follows that comparisons of our estimated education coefficients across time and across countries must not necessarily only reflect changes in the private return to education.

In the second step we add as explanatory variable three dummy variables indicating occupation, five dummies for production sector and also three dummy variables for

\footnotetext{
${ }^{7}$ We have also compared Lorenz-curves for the variables reported in Table 2 and found that the one for urban China 2002 crosses the one for urban Russia 2003.
} 
ownership sector. This set of explanatory variables is used in the third and final step where we estimate quintile regressions in order to detect if the relationship between the explanatory variable and earnings varies across the earnings distribution.

\section{/Table 3 about here/}

The results from estimating the parsimonious earnings function for both countries are reported in Table 3. Much of the pattern is expected from the bivariate analysis presented in Table 2. Estimated coefficients which express how personal characteristics are related to log earnings are more or less identical whether or not the dependent variable is adjusted for spatial price differences. The coefficient for being male on earnings is estimated to 0.44 for the Russian sample as compared to 0.28 in the Chinese sample. In contrast the coefficients for the education dummies are much higher in the Chinese sample. For example the coefficient for at least a college education is 1.00 in the Chinese sample but not higher than 0.41 in the Russian sample.

Earnings increase by age in urban Russia up to age group 41 to 45 after which they decrease. In contrast, earnings in urban China continue to increase up to age group 51 to 55 and thereafter there are few differences by age. Consistent with the bivariate analysis we find that how the earnings variable is defined affects the magnitude of the coefficients for the spatial variables. In the preferred alternative by which spatial price differences are considered in the definition of the dependent variable, we report for urban China the highest coefficient for living in the most developed coastal region and in a provincial capital. For Russia the highest coefficients are for living in the northwestern region and in the Ural region.

\section{/Table 4 about here/}

In the full specification we add further variables that were introduced in Section 4 measuring occupation and economic sector. The transition process has also led to new forms of ownership, and we therefore also introduce dummy variables for the three ownerships public, private and foreign. This specification is (with the exception of ownership dummies) highly comparable with that applied for studying earnings determination at the end of the 1980s (see Gustafsson et al, 2001), and we will therefore also comment on changes in coefficients over time. Supplementing the OLS-estimates reported in Table 4 we report the results from the quintile regressions using figures.

\section{/ Figure 3 about here/}

As gender and education on the one hand and occupation, economic sector and ownership on the other can be correlated, Table 5 shows that in this specification coefficients for gender and education not surprisingly are generally lower than in the parsimonious specification (Table 4). The coefficients for occupation are larger in the Russian sample and in this specification the coefficients for education are lower, indicating that much of the relation reported in the parsimonious specification is channeled through occupation. The corresponding is not the case in the Chinese sample. The coefficient for male in China in 2002 (0.19) reported in Table 5 is higher than in the estimates for the end of the 1980s (0.13). The increase in the gender wage gap in China since the 1980s obtained from earnings functions has also been reported by $\mathrm{Ng}$ (2007), Liu (2011), Appleton et al (2012) and Chi and $\mathrm{Li}$ (2013). The corresponding coefficient from the Russia sample 2003 is 0.40 , thus roughly 
two times as large as in China 2002 and close to the estimate for Russia at the end of the 1980s (0.38).

We have thus found some signs in convergence in the gender wage gap across countries, but still at the beginning of the new millennium the gender wage gap is much higher in urban Russia. Figure 3 shows that across the earnings distribution the coefficient for being male is more or less horizontal in Russia. In contrast the premium of being male is highest in the lower end of the Chinese distribution, which is consistent with what is reported by Chi and $\mathrm{Li}$ (2008). The cross-country difference in the gender wage gap is largest at the top of the distribution where the coefficient for Russia is three times as large as for China.

/Figure 4 about here/

We now turn to the coefficients for the education dummies finding that consistent with results from the parsimonious specification, those reported in Table 4 are higher in the Chinese sample. For example the coefficient for college and above compared to basic education is 0.77 in the Chinese sample and not more than 0.30 in the Russian sample. This is a large difference compared to the results from the 1980s when the opposite was the case and consistent with what has been reported from previous studies. Please note that here we are comparing Russia at a point in time when the consequences of the expansion of higher education had started to be felt in the labour market, while this had yet to be experienced in China. Figure 4 illustrates that the cross-country difference is largest for the highest education category. The same figure also illustrates that coefficients for education are similar across the earnings distribution in the Chinese, but not the Russian sample.

/Figure 5 about here/

In the estimates of the full specification of the earnings function reported in Table 5, coefficients indicate a positive earnings association effect for having occupations other than manual worker. The coefficients are in both countries not surprisingly highest for being employed as manager or in official occupations. Figure 5 shows coefficients across the earnings distribution for the occupations: a. office worker, b. professional and c. manager and official. In all cases they are considerably higher in the Russian sample. The payoff of being an office worker is highest at the bottom of the Russian sample, and declines to be rather low at the top of the earnings distribution. The payoff of being a professional is similar across countries at the bottom of the earning distribution and falls thereafter in the Chinese sample. Only with the exception of a position at the very low end of the earnings distribution are the coefficients for being manager and official larger in the Russian sample.

/Figure 6 about here/

Turning to coefficients for economic sector with manufacturing as the omitted category, we find in Table 4 some similarities across samples: negative coefficients for the sector trade and services which, as also illustrated in Figure 6, are largest in the Russian sample, particularly at the lowest part of the earnings distribution. Table 4 shows very small coefficients estimated with low t-statistics for the sector construction. However, Figure 6 shows a main exception with a relatively high coefficient at the top of the Chinese earnings distribution. 
The coefficient for the public service sector reported in Table 4 differs greatly across countries. It is positive in the Chinese sample (0.12) and estimated with high t-statistics. The latter is different from the study of the situation at the end of the 1980s when the corresponding coefficient was estimated with low t-statistics. The negative coefficient in the Russian sample (-0.26) is twice as large as in the study for the end of the 1980s. Figure 6 shows that the coefficients for public sector are of the same negative magnitude throughout almost all of the earnings distribution in Russia. Exceptions from a positive coefficient for the public sector in China are found in the two tales of the earnings distribution.

\section{/Figure 7 about here/}

Finally, when inspecting coefficients for ownership (other than public) we find some results to comment on. The coefficient for private ownership is small and negative according to Figure 7 across most of the earnings distribution in China, with the exception of a substantial positive effect at the top of the earnings distribution. In the Russian sample the coefficients of private ownership are generally small. Larger coefficients are reported for the variable foreign ownership. The coefficients reported in Table 5 are equally large in the two samples and estimated with a high t-value in both samples. Figure 7 shows that coefficients are similar across countries for almost all of the earnings distribution. The exceptions are in the Russian sample; at the low end, where the coefficient is negative, and at the top of the distribution, where the coefficient is exceptionally high.

\section{Conclusions}

China and Russia have both had a planned socialist system and both have taken many steps towards a labour market of western style. Surprisingly few attempts have been made to compare labor market and income determination in the two countries and we hope our example will stimulate other efforts. In this paper we have used data collected in urban China 2002 and urban Russia 2003 to compare earnings inequality and earnings determination. As a similar study had previously been made, it was possible to put the findings in perspective of the situation in the two countries at the end of the 1980s. We supplemented the conventional earnings regression analysis applying OLS with estimating quintile regressions. The latter analysis showed that is some cases it can be misleading to generalize the findings to the entire earnings distribution. Particularly earnings determination at the top of the earnings distribution can appear notably different from what a conventional regression analysis shows.

The study confirms that earnings inequality has increased rapidly in China as well as in Russia. For example, the Gini for earnings among all workers of all ages defined in the same manner went up from 0.25 to 0.37 in both countries. The analysis has shown large continuity in some aspects of earnings determination in the two countries and thereby persistency in cross-country differences. Earnings functions analysis shows that in urban Russia earnings reach a maximum at age 41 to 45 , while in urban China the positive relationship between age and earnings continues up to higher ages. Earnings function analysis also indicates a slight convergence across the two countries in the gender wage gap as the gap has tended to increase in China. Still, at the end of the millennium the gender earning gap was larger in Russia, particularly at the top of the distribution. These results suggest that earnings 
determination is embedded in social norms that persist even during periods of large societal change.

However, we have also found changes across time and different developments between urban China and urban Russia. These changes can be attributed to changed supply and demand of labour in the two countries and to changes in the wage-setting mechanism. The association between education and income in urban China increased rapidly in strength from being lower than in Russia during the Soviet period to become higher. We interpret this difference across countries as the outcome of rapid increase in the demand for skilled workers in China in combination with rapid increase of supply of less-skilled workers due to large rural to urban migration. However, please note that results from other studies that have analyzed more recent data indicate that the increase in the association between education and earnings in China has come to a halt, and possibly also been somewhat reversed after the time at which the data we have analyzed here was collected. The latest development in China is driven by the rapid recent expansion of higher education.

The other major change is the divergence across time in the payoff from being employed in the government service sector. For China it means a change from a not significant coefficient in the earnings function analysis to a positive coefficient of modest magnitude; for Russia increased magnitude of a negative coefficient. The Russian development can be traced to the large funding problems the Russian public sector has faced since the introduction of economic reforms. In contrast most workers in the Chinese public sector have been able to benefit from the rapidly growing economy. The two countries share the finding that the few percent of all workers employed in foreign enterprises enjoy a substantial earnings premium.

Behind the cross-country differences in supply and demand factors lie differences in initial conditions as well as differences in the process of transition from a planned to a market economy. An important different initial condition was that China was much less urbanized than Russia and that the urban-rural income gap was larger. The large inflow of unskilled rural workers to urban China, in combination with rapid economic growth, helps to understand why the association between education and earnings increased more rapidly in China than in Russia. The differences in growth experiences also contribute to understand why the payoff from being employed in government social service developed differently in the two countries. 


\section{References}

Appleton, S., Song, L. Xia, Q. (2005) "Has China Crossed the River? The Evolution of Wage Structure in Urban China during Reform and Retrenchment", Journal of Comparative Economics, 33, 644-663.

Appleton, S., Song, L. and Xia, Q. (2012) "Understanding Urban Wage Inequality in China 1988 - 2008: Evidence from Quintile Analysis", Institute for the Study of Labor Bonn, Discussion Paper No 7101.

Brandt, L. and C.A. Holz (2006), "Spatial Price Differences in China: Estimates and Implications," Economic Development and Cultural Change, 55(1), 43-86.

Cai, F., A. Park, and Y. Zhao (2008), "The Chinese Labor Market in the Reform Era," in L. Brandt and T. G. Rawski eds., China's Great Economic Transformation, 167-214, New York: Cambridge University Press.

Carnoy, M., Loyalka, P., Androushchak, G. and Proudnikova, A. (2012) "The Economic Returns to Higher Education in the BRIC Countries and Their Implications for Higher Education Expansion", Higher School of Economics Research Paper no. WP BRP 02/EDU/2012. Available at SSRB: htpp://ssrn.com

Chi, W. and Li, B. (2008) "Glass Ceiling or Sticky Floor? Examining the Gender Earnings Differential Across the Earnings Distribution in Urban China 1987 - 2004", Journal of Comparative Economics, 36, 243-263.

Chi, W. and Li, B. (2013) "Trends in China's Gender Earnings and Pay Gap: Estimating Gender Pay Gaps with Employment Selection", Journal of Comparative Economics, Article in Press.

Entov, R. M. and Lugovoy, O.E. (2013) "Growth Trends in Russia after 1998” in Alexeev, M. and Weber, S. (Eds) The Oxford Handbook of the Russian Economy, Oxford: Oxford University Press.

Fleisher, B. and Wang, X. (2005) "Returns to Schooling in China under Planning and Reform", Journal of Comparative Economics, 33, 265-277.

Gimpelson, V. and Kapeliushnikov, R, (2013) "Labor Market Adjustment: Is Russia Different?" in Alexeev, M. and Weber, S. (Eds) The Oxford Handbook of the Russian Economy, Oxford: Oxford University Press.

Gimpelson, V and Lukyanova, A. (2009) "Are Public Sector Workers Underpaid in Russia? Estimating the Public-Private Wage Gap", Institute for the Study of Labor, Bonn, Discussion Paper No. 3941.

Gorodnichenko, Y. Nad Sabirianova, P. (2005) Returns to Schooling in Russia and Ukraine: A Semiparametric Approach to Cross-country Comparative Analysis" Journal of Comparative Economics, 33, 324-350. 
Gustafsson, B. Li, S., Nivorozhkina, L. and Katz, K. (2001) "Roubles and Yuan: Wage Functions for Urban Rusia and China at the End of the 1980s", Economic Development and Cultural Change, 50 (1), 1- 17.

Gustafsson, B. and Ding, S. (2013) "Unemployment and the Rising Number of Non-Workers in Urban China: Causes and Distributional Consequences" in Li, S., Sato, H. and Sicular, T. (Eds) Rising Inequality in China, Cambridge: Cambridge University Press.

Kaganovich, M. (2013) "Higher Education Reform and Access to College in Russia" in Alexeev, M. and Weber, S. (Eds) The Oxford Handbook of the Russian Economy, Oxford: Oxford University Press.

Katz, K. (2001) Gender, Work and Wages in the Soviet Union. A Legacy of Discrimination, Houndmills, Basingstoke: Palgrave.

Knight, J. and Song, L. (2008) “China's Emerging Urban Wage Structure, 1995-2002” in B.A. Gustafsson, S. Li, and T. Sicular, eds., Inequality and Public Policy in China, New York: Cambridge University Press

Li, S., C. Luo, Z. Wei, and X. Yue (2008), "Appendix: The 1995 and 2002 Household Surveys: Sampling Methods and Data Description," in B.A. Gustafsson, S. Li, and T. Sicular, eds., Inequality and Public Policy in China, 337-354, Cambridge: Cambridge University Press.

Li, S. and J. Song (2013), "Changes in Gender Wage Gap in Urban China, 1995- 2007," in Li, S., Sato, H. and Sicular, T. (Eds) Rising Inequality in China, Cambridge: Cambridge University Press.

Liu, H. (2011) "Economic Reforms and Gender Inequality in Urban China", Economic Development and Cultural Change, 59 (4), 839-876.

Lukyanova, A. (2006) "Wage Inequality in Russia (1994-2003)", Moscow: Economic and Education Research Consortium, Working Papers Series No06/03.

Meng, X. (2012) "Labor Market Outcome and Reform in China", Journal of Economic Perspecitves, 26 (4), 75-102.

Meng, X., Shen, K. and Xue, S. (2013) "Economic Reform, Education Expansion, and Earnings Inequality for Urban Males in China, 1988-2009”, Journal of Comparative Economics, 41, 227-244.

Mincer, J. (1974) Schooling, Experience and Earnings, New York: Columbia University Press for National Bureau of Economic Research.

Ng, Y. C. (2007) “"'Gender Earnings Differentials and Regional Economic Development in Urban China, 1988-97", Review of Income and Wealth, 53, 148-166. 
Popov, V. (2013) "Transformational Recession" in Alexeev, M. and Weber, S. (Eds) The Oxford Handbook of the Russian Economy, Oxford: Oxford University Press.

Yang, J. , Démurger, S. and Li S. (2013) "Do Employees in the Public Sector Still Enjoy Earnings Advantages?" in Li, S., Sato, H. and Sicular, T. (Eds) Rising Inequality in China, Cambridge: Cambridge University Press.

Zhang, J., Y. Zhao, A. Park, and X. Song (2005), "Economic Returns to Schooling in Urban China 1988 to 2001," Journal of Comparative Economics, 33(4), 730-752.

Zhou, X. (2000) "Transformation and Income Inequality in Urban China: Evidence from Panel Data", American Journal of Sociology, 105 (4), 1135-1174. 
Table 1. Labour Structure and Mean of Earnings in Urban China and Urban Russia

\begin{tabular}{|c|c|c|c|c|c|c|}
\hline \multirow[t]{2}{*}{ Variables } & \multicolumn{3}{|c|}{ China } & \multicolumn{3}{|l|}{ Russia } \\
\hline & $\begin{array}{l}\text { Sample } \\
\text { Mean } \\
(\%)\end{array}$ & $\begin{array}{l}\text { Mean of } \\
\text { Total } \\
\text { wage as } \\
\text { Percentage } \\
\text { of } \\
\text { Average }\end{array}$ & $\begin{array}{l}\text { Mean of } \\
\text { Total } \\
\text { wage as } \\
\text { Percentage } \\
\text { of } \\
\text { Average } \\
\text { corrected } \\
\text { by } \\
\text { regional } \\
\text { cost of life }\end{array}$ & \begin{tabular}{|l|} 
Sample \\
Mean \\
$(\%)$
\end{tabular} & $\begin{array}{l}\text { Mean of } \\
\text { Total } \\
\text { wage as } \\
\text { Percentage } \\
\text { of } \\
\text { Average }\end{array}$ & $\begin{array}{l}\text { Mean of } \\
\text { Total } \\
\text { wage as } \\
\text { Percentage } \\
\text { of } \\
\text { Average } \\
\text { corrected } \\
\text { by } \\
\text { regional } \\
\text { cost of life }\end{array}$ \\
\hline \multicolumn{7}{|l|}{ Gender: } \\
\hline Male & 55.35 & 109.22 & 109.43 & 47.0 & 122.4 & 122.4 \\
\hline Female & 44.65 & 88.56 & 88.29 & 53.0 & 80.1 & 80.1 \\
\hline \multicolumn{7}{|l|}{ Age group: } \\
\hline $16-20$ & 0.91 & 49.07 & 48.95 & 3.1 & 65.5 & 67.1 \\
\hline $21-25$ & 6.22 & 75.18 & 73.07 & 10.5 & 90.9 & 92.6 \\
\hline $26-30$ & 8.05 & 84.74 & 84.94 & 11.6 & 103.4 & 103.1 \\
\hline $31-35$ & 14.40 & 93.72 & 95.11 & 10.7 & 104.9 & 105.1 \\
\hline $36-40$ & 19.81 & 99.57 & 101.54 & 11.1 & 105.8 & 107.2 \\
\hline $41-45$ & 17.82 & 99.47 & 99.08 & 14.6 & 106.5 & 106.9 \\
\hline $46-50$ & 18.90 & 108.62 & 107.68 & 15.9 & 103.7 & 104.2 \\
\hline $51-55$ & 9.90 & 117.75 & 115.86 & 12.7 & 103.6 & 102.1 \\
\hline $56-60$ & 3.23 & 124.36 & 122.92 & 4.9 & 99.4 & 95.5 \\
\hline 60 and over & 0.76 & 111.82 & 112.49 & 4.9 & 69.9 & 67.2 \\
\hline Median age & 40.55 & & & 41 & & \\
\hline \multicolumn{7}{|l|}{ Education: } \\
\hline College and above & 10.71 & 148.47 & 148.61 & 27.4 & 124.1 & 122.9 \\
\hline Technical school & 36.04 & 110.11 & 110.09 & 38.0 & 96.9 & 96.6 \\
\hline Upper middle & 28.04 & 89.62 & 89.21 & 24.5 & 85.7 & 87.3 \\
\hline Lower middle & 22.59 & 78.08 & 78.42 & 10.0 & 80.8 & 81.3 \\
\hline Primary and below & 2.62 & 64.50 & 65.67 & 0.1 & 88.4 & 87.9 \\
\hline \multicolumn{7}{|l|}{ Occupation: } \\
\hline Manual worker & 32.57 & 82.43 & 83.20 & 37.6 & 93.9 & 95.6 \\
\hline Office worker & 34.01 & 90.34 & 89.49 & 41.7 & 89.6 & 88.6 \\
\hline Professional & 22.51 & 122.79 & 122.96 & 18.2 & 125.2 & 123.6 \\
\hline Manager and official & 10.92 & 138.89 & 138.75 & 2.5 & 177.4 & 179.6 \\
\hline \multicolumn{7}{|l|}{ Economic sector: } \\
\hline Manufacturing & 25.97 & 86.03 & 86.65 & 26.3 & 107.5 & 111.6 \\
\hline Construction & 3.29 & 107.00 & 103.24 & 8.6 & 120.7 & 118.5 \\
\hline Transportation & 7.70 & 108.15 & 108.21 & 9.9 & 114.9 & 112.2 \\
\hline Trade and service & 15.71 & 91.31 & 89.59 & 27.0 & 97.3 & 95.1 \\
\hline Public service & 39.51 & 111.65 & 111.91 & 26.0 & 84.1 & 84.1 \\
\hline Other & 7.81 & 88.45 & 88.88 & 1.4 & 85.8 & 84.5 \\
\hline \multicolumn{7}{|l|}{$\begin{array}{l}\text { Ownership type of } \\
\text { firm/enterprise }\end{array}$} \\
\hline State/sub-federal, & 64.81 & 96.83 & 97.63 & 62.6 & 97.8 & 96.7 \\
\hline
\end{tabular}




\begin{tabular}{|c|c|c|c|c|c|c|}
\hline \multicolumn{7}{|l|}{$\begin{array}{l}\text { Municipal and Public } \\
\text { association }\end{array}$} \\
\hline Private & 28.65 & 88.34 & 87.22 & 26.8 & 97.5 & 99.6 \\
\hline $\begin{array}{l}\text { Foreign ownership } \\
\text { and mixed with both } \\
\text { domestic and foreign } \\
\text { ownership }\end{array}$ & 3.10 & 132.53 & 124.17 & 1.0 & 152.9 & 151.8 \\
\hline Others / No answer & 3.43 & 75.45 & 71.78 & 9.7 & 116.1 & 117.6 \\
\hline \multicolumn{7}{|l|}{ Settlements } \\
\hline $\begin{array}{l}\text { Moscow and } \mathrm{S} \\
\text { Petersburg } \\
\text { (Municipalities) }\end{array}$ & 8.52 & 153.91 & 128.45 & 18.5 & 138.2 & 108.6 \\
\hline $\begin{array}{l}1 \text { million people and } \\
\text { more } \quad \text { (Province } \\
\text { capital) }\end{array}$ & 26.46 & 104.76 & 105.36 & 10,9 & 86.6 & 99.5 \\
\hline $\begin{array}{l}500,000-999,900 \\
\text { (other cities) }\end{array}$ & 65.03 & 90.97 & 94.08 & 13,5 & 92,7 & 102.6 \\
\hline \multicolumn{7}{|l|}{$20,000-499,900(/)$} \\
\hline \multicolumn{7}{|l|}{$\begin{array}{l}\text { Federal districts } \\
\text { Russia (China) }\end{array}$} \\
\hline The Central(Central) & 35.00 & 81.72 & 87.58 & 29.8 & 111.6 & 102.1 \\
\hline $\begin{array}{l}\text { The North-West; } \\
\text { ( Northwest) }\end{array}$ & 5.69 & 82.88 & 87.98 & 12.5 & 124.5 & 112.5 \\
\hline $\begin{array}{ll}\text { The } & \text { South } \\
\text { (Southwest) }\end{array}$ & 21.17 & 91.83 & 99.12 & 10.7 & 68.3 & 84.8 \\
\hline $\begin{array}{l}\text { The Privozhsky } \\
\text { (Volga) (Coastal) }\end{array}$ & 18.98 & 128.79 & 117.65 & 20.7 & 74.8 & 90.6 \\
\hline $\begin{array}{l}\text { The Urals } \\
\text { (municipality) }\end{array}$ & 8.52 & 106.14 & 128.45 & 8.5 & 119.9 & 112.2 \\
\hline The Siberia & & & & 13.4 & 104.1 & 106.1 \\
\hline $\begin{array}{l}\text { The Far } \quad \text { East } \\
\text { (Northeast) }\end{array}$ & 10.64 & 78.00 & 94.39 & 4.4 & 118.1 & 88.8 \\
\hline
\end{tabular}

Source: Authors' calculations from CHIP 2002 and NOBUS 2003

Note: For definitions of variables see Appendix 1. 
Table 2

Gini coefficients for earnings in urban China and urban Russia at the end of the 1980s and 2002/2003

\begin{tabular}{|l|l|l|l|l|l|l|}
\hline \multicolumn{3}{|l|}{ All workers } & $\begin{array}{l}\text { End of the } \\
\mathbf{1 9 8 0 s}\end{array}$ & $\mathbf{2 0 0 2 / 2 0 0 3}$ & \multicolumn{2}{l|}{$\begin{array}{l}\text { Workers 25 - 55 } \\
\text { 1980s }\end{array}$} \\
\hline $\begin{array}{l}\text { Correction } \\
\text { for } \\
\text { regional } \\
\text { price } \\
\text { differences }\end{array}$ & No & No & Yes & No & No & Yes \\
\hline $\begin{array}{l}\text { Males and } \\
\text { females }\end{array}$ & & & & & & \\
\hline China & 0.252 & 0.370 & 0.356 & 0.227 & 0.370 & 0.355 \\
\hline Russia & 0.251 & 0.374 & 0.344 & 0.241 & 0.344 & 0.337 \\
\hline & & & & & & \\
\hline Males & & & & & & \\
\hline China & 0.246 & 0.347 & 0.332 & 0.219 & 0.348 & 0.332 \\
\hline Russia & 0.227 & 0.360 & 0.328 & 0.212 & 0.352 & 0.318 \\
\hline & & & & & & \\
\hline Females & & & & & & \\
\hline China & 0.247 & 0.380 & 0.366 & 0.224 & 0.380 & 0.366 \\
\hline Russia & 0.216 & 0.345 & 0.320 & 0.206 & 0.349 & 0.313 \\
\hline
\end{tabular}

Source: Gustafsson et al (2001) and authors' calculations from CHIP 2002 and NOBUS 2003 
Table 3. Estimates of semilog wage functions for China 2002 and Russia 2003 (dependent variable: log total wage) Full Sample with reduced specification

\begin{tabular}{|c|c|c|c|c|c|c|c|c|}
\hline & $(1)$ & $(2)$ & (3) & (4) & $(5)$ & $(6)$ & $(7)$ & $(8)$ \\
\hline & \multicolumn{4}{|c|}{ CHINA } & \multicolumn{4}{|c|}{ RUSSIA } \\
\hline & \multicolumn{2}{|c|}{ without adjustment } & \multicolumn{2}{|c|}{ with adjustment } & \multicolumn{2}{|c|}{ without adjustment } & \multicolumn{2}{|c|}{ With adjustment } \\
\hline LABELS & coef & se & coef & $\mathrm{Se}$ & Coef & se & coef & se \\
\hline \multicolumn{9}{|l|}{ Female omitted } \\
\hline Male & $0.280 * * *$ & $(0.011)$ & $0.279 * * *$ & $(0.011)$ & $0.446 * * *$ & $(0.007)$ & $0.443 * * *$ & $(0.007)$ \\
\hline college and above & $0.999 * * *$ & $(0.030)$ & $0.996 * * *$ & $(0.030)$ & $0.415 * * *$ & $(0.013)$ & $0.410 * * *$ & $(0.013)$ \\
\hline technical school & $0.741 * * *$ & $(0.026)$ & $0.741 * * *$ & $(0.026)$ & $0.188 * * *$ & $(0.013)$ & $0.183 * * *$ & $(0.012)$ \\
\hline upper middle & $0.429 * * *$ & $(0.027)$ & $0.432 * * *$ & $(0.026)$ & $0.068 * * *$ & $(0.013)$ & $0.073 * * *$ & $(0.013)$ \\
\hline $\begin{array}{c}\text { lower middle } \\
\text { below middle omitted } \\
\text { Under } 21 \text { omitted }\end{array}$ & $0.204 * * *$ & $(0.026)$ & $0.210 * * *$ & $(0.026)$ & & & & \\
\hline $21-25$ & $1.119 * * *$ & $(0.111)$ & $1.124 * * *$ & $(0.111)$ & $0.234 * * *$ & $* 0.023)$ & $0.234 * * *$ & $(0.022)$ \\
\hline $26-30$ & $1.343 * * *$ & $(0.109)$ & $1.344 * * *$ & $(0.109)$ & $0.344 * * *$ & $(0.023)$ & $0.340 * * *$ & $(0.022)$ \\
\hline $31-35$ & $1.532 * * *$ & $(0.108)$ & $1.533 * * *$ & $(0.107)$ & $0.375 * * *$ & $(0.023)$ & $0.373 * * *$ & $*(0.022)$ \\
\hline $36-40$ & $1.619 * * *$ & $(0.107)$ & $1.620 * * *$ & $(0.106)$ & $0.375 * * *$ & $(0.023)$ & $0.380 * * *$ & $(0.022)$ \\
\hline $41-45$ & $1.634 * * *$ & $(0.107)$ & $1.630 * * *$ & $(0.107)$ & $0.411 * * *$ & $(0.022)$ & $0.414 * * *$ & $(0.022)$ \\
\hline $46-50$ & $1.677 * * *$ & $(0.107)$ & $1.675 * * *$ & $(0.107)$ & $0.384 * * *$ & $(0.022)$ & $0.385 * * *$ & $(0.021)$ \\
\hline $51-55$ & $1.712 * * *$ & $(0.107)$ & $1.713 * * *$ & $(0.107)$ & $0.353 * * *$ & $(0.022)$ & $0.350 * * *$ & $(0.022)$ \\
\hline $56-60$ & $1.678 * * *$ & $(0.108)$ & $1.689 * * *$ & $(0.108)$ & $0.248 * * *$ & $(0.026)$ & $0.238 * * *$ & $(0.025)$ \\
\hline 61-over & $1.706 * * *$ & $(0.108)$ & $1.723 * * *$ & $(0.107)$ & $-0.115 * *$ & $(0.026)$ & $-0.124 * *$ & $(0.025)$ \\
\hline Municipality (Central) & $0.618 * * *$ & $(0.043)$ & $0.352 * * *$ & $(0.043)$ & $0.282 * * *$ & $(0.013)$ & $0.181 * * *$ & $(0.013)$ \\
\hline Northeast (North West) & -0.034 & $(0.037)$ & -0.015 & $(0.037)$ & $0.372 * * *$ & $(0.016)$ & $0.294 * * *$ & $(0.015)$ \\
\hline Costal (Volga) & $0.353 * * *$ & $(0.031)$ & $0.247 * * *$ & $(0.031)$ & $0.090 * * *$ & $(0.015)$ & $0.052 * * *$ & $(0.013)$ \\
\hline Central (Ural) & -0.021 & $(0.027)$ & 0.004 & $(0.027)$ & $0.483 * * *$ & $(0.017)$ & $0.248 * * *$ & $(0.016)$ \\
\hline Southwest (Siberia) & $0.107 * * *$ & $(0.030)$ & $0.127 * * *$ & $(0.030)$ & $0.349 * * *$ & $(0.015)$ & $0.159 * *$ & $(0.014)$ \\
\hline (Far East) & & & & & $0.546 * * *$ & $(0.020)$ & $0.056 * * *$ & $(0.019)$ \\
\hline Beijing (Moscow S.P.) & $0.056 *$ & $(0.031)$ & $0.090 * * *$ & $(0.032)$ & $0.495 * * *$ & $0.012)$ & $0.143 * * *$ & $(0.012)$ \\
\hline $\begin{array}{c}\text { Provincial capitals (million } \\
\text { and larger cities) }\end{array}$ & $0.188 * * *$ & $(0.020)$ & $0.149 * * *$ & $(0.020)$ & $0.057 * * *$ & $(0.014)$ & $0.104 * * *$ & $(0.013)$ \\
\hline $\begin{array}{c}\text { prefecture level cities } \\
(500000-99999)\end{array}$ & $0.100 * * *$ & $(0.019)$ & $0.116^{* * *}$ & $(0.020)$ & $0.086 * * *$ & $0.012)$ & $0.120 * * *$ & $*(0.012)$ \\
\hline (100-499 999) & & & & & $0,025 * *$ & $(0,009)$ & $0.040 * * *$ & $(0.009)$ \\
\hline \multirow[t]{3}{*}{ Constant } & $6.656 * * *$ & $(0.113)$ & $6.512 * * *$ & $(0.112)$ & $7.008 * * *$ & $(0.026)$ & $7.127 * * *$ & $(0.025)$ \\
\hline & 14763 & & 14763 & & 27496 & & 27496 & \\
\hline & 0.284 & & 0.252 & & 0.301 & & 0.226 & \\
\hline
\end{tabular}

Sources: Authors' estimates from CHIP 2002 and NOBUS 2003.

Note: For definitions of variables see Appendix 1. 
Table 4. Estimates of semilog wage functions for China 2002 and Russia 2003 (dependent variable: log total wage) Full Sample

\begin{tabular}{|c|c|c|c|c|c|c|c|c|}
\hline & (1) & (2) & (3) & (4) & (5) & $(6)$ & (7) & $(8)$ \\
\hline & \multicolumn{4}{|c|}{ China } & \multicolumn{4}{|c|}{ Russia } \\
\hline & \multicolumn{2}{|c|}{ Without adjustment } & \multicolumn{2}{|c|}{ With adjustment } & \multicolumn{2}{|c|}{ without adjustment } & \multicolumn{2}{|c|}{ With adjustment } \\
\hline VARIABLES & coef & se & coef & se & coef & se & coef & se \\
\hline \multicolumn{9}{|l|}{ Female omitted } \\
\hline $\begin{array}{l}\text { Male } \\
\text { Below } 21\end{array}$ & $0.189 * * *$ & $(0.011)$ & $0.187 * * *$ & $(0.011)$ & $0.408 * * *$ & $(0.007)$ & $0.403 * * *$ & $(0.007)$ \\
\hline $21-25$ & $0.961 * * *$ & $(0.102)$ & $0.967 * * *$ & $(0.102)$ & $0.227 * * *$ & $(0.022)$ & $0.226 * * *$ & $(0.021)$ \\
\hline $26-30$ & $1.145 * * *$ & $(0.101)$ & $1.147 * * *$ & $(0.100)$ & $0.329 * * *$ & $(0.022)$ & $0.325 * * *$ & $(0.021)$ \\
\hline $31-35$ & $1.329 * * *$ & $(0.099)$ & $1.329 * * *$ & $(0.099)$ & $0.353 * * *$ & $(0.022)$ & $0.351 * * *$ & $0.021))$ \\
\hline $36-40$ & $1.409 * * *$ & $(0.098)$ & $1.410 * * *$ & $(0.098)$ & $0.353 * * *$ & $(0.022)$ & $0.356 * * *$ & $(0.021)$ \\
\hline $41-45$ & $1.441 * * *$ & $(0.099)$ & $1.436 * * *$ & $(0.098)$ & $0.384 * * *$ & $(0.022)$ & $0.385 * * *$ & $(0.021)$ \\
\hline $46-50$ & $1.513 * * *$ & $(0.099)$ & $1.510 * * *$ & $(0.098)$ & $0.351 * * *$ & $(0.022)$ & $0.350 * * *$ & $(0.021)$ \\
\hline $51-55$ & $1.621 * * *$ & $(0.099)$ & $1.621 * * *$ & $(0.099)$ & $0.310 * * *$ & $(0.022)$ & $0.306^{* * * *}$ & $(0.021)$ \\
\hline $56-60$ & $1.683 * * *$ & $(0.101)$ & $1.693 * * *$ & $(0.100)$ & $0.212 * * *$ & $(0.025)$ & $0.199 * * *$ & $(0.024)$ \\
\hline 61-over & $1.847 * * *$ & $(0.101)$ & $1.864 * * *$ & $(0.100)$ & $-0.103 * *$ & $(0.025)$ & $-0.112 * *$ & $(0.024)$ \\
\hline college and above & $0.776 * * *$ & $(0.030)$ & $0.773 * * *$ & $(0.030)$ & $0.299 * * *$ & $(0.014)$ & $0.297 * * *$ & $(0.014)$ \\
\hline technical school & $0.578 * * *$ & $(0.026)$ & $0.578 * * *$ & $(0.026)$ & $0.164 * * *$ & $(0.012)$ & $0.159 * * *$ & $(0.012)$ \\
\hline upper middle & $0.377 * * *$ & $(0.026)$ & $0.380 * * *$ & $(0.026)$ & $0.060 * * *$ & $(0.013)$ & $0.064 * * *$ & $(0.012)$ \\
\hline lower middle & $0.211 * * *$ & $(0.026)$ & $0.217 * * *$ & $(0.026)$ & & & & \\
\hline \multicolumn{9}{|l|}{$\begin{array}{l}\text { below lower middle } \\
\text { (C) or upper middle } \\
\text { (R) omitted }\end{array}$} \\
\hline office worker & $0.379 * * *$ & $(0.020)$ & $0.375 * * *$ & $(0.020)$ & $0.113 * * *$ & $(0.009)$ & $0.110 * * *$ & $(0.008)$ \\
\hline $\begin{array}{l}\text { professional and } \\
\text { managers }\end{array}$ & $0.461 * * *$ & $(0.018)$ & $0.463 * * *$ & $(0.018)$ & $0.288 * * *$ & $(0.013)$ & $0.284 * * *$ & $(0.012)$ \\
\hline Officials & $0.520 * * *$ & $(0.023)$ & $0.520 * * *$ & $(0.023)$ & $0.536 * * *$ & $(0.024)$ & $0.522 * * *$ & $(0.023)$ \\
\hline Construction & 0.011 & $(0.039)$ & 0.005 & $(0.039)$ & 0.005 & $(0.014)$ & -0.013 & $(0.013)$ \\
\hline Transportation & $0.176 * * *$ & $(0.025)$ & $0.183 * * *$ & $(0.025)$ & $0.045 * * *$ & $(0.013)$ & $0.029 * * *$ & $(0.013)$ \\
\hline Trade and service & $-0.151 * * *$ & $(0.020)$ & $-0.149 * * *$ & $(0.020)$ & $-0.129 * *$ & $(0.010)$ & $-0.142 * *$ & $(0.010)$ \\
\hline Public service & $0.110 * * *$ & $(0.021)$ & $0.120 * * *$ & $(0.021)$ & $-0.252 * *$ & $(0.011)$ & $-0.260 * *$ & $(0.010)$ \\
\hline Other & -0.002 & $(0.018)$ & -0.003 & $(0.018)$ & $-0.292 * *$ & $(0.030)$ & $-0.294 * *$ & $(0.029)$ \\
\hline \multicolumn{9}{|l|}{$\begin{array}{l}\text { Manual worker } \\
\text { omitted }\end{array}$} \\
\hline Private & $0.053 * * *$ & $(0.018)$ & $0.047 * * *$ & $(0.018)$ & -0.011 & $(0.009)$ & -0.006 & $(0.009)$ \\
\hline Foreign & $0.296 * * *$ & $(0.046)$ & $0.295 * * *$ & $(0.045)$ & $0.278 * * *$ & $(0.035)$ & $0.301 * * *$ & $(0.034)$ \\
\hline Others & $0.182 * * *$ & $(0.015)$ & $0.177 * * *$ & $(0.015)$ & $0.085 * * *$ & $(0.012)$ & $0.101 * * *$ & $(0.012)$ \\
\hline \multicolumn{9}{|l|}{$\begin{array}{l}\text { State/sub-federal, } \\
\text { Municipal and Public } \\
\text { associations omitted }\end{array}$} \\
\hline Municipality (Central) & $0.579 * * *$ & $(0.041)$ & $0.315 * * *$ & $(0.041)$ & $0.271 * * *$ & $(0.013)$ & $0.170 * * *$ & $(0.013)$ \\
\hline $\begin{array}{l}\text { Northeast (North- } \\
\text { West) }\end{array}$ & -0.007 & $(0.036)$ & 0.013 & $(0.036)$ & $0.352 * * *$ & $(0.016)$ & $0.272 * * *$ & $(0.015)$ \\
\hline Coastal $($ Volga $)$ & $0.359 * * *$ & $(0.030)$ & $0.253 * * *$ & $(0.030)$ & $0.077 * * *$ & $(0.013)$ & $0.038 * *$ & $(0.013)$ \\
\hline Central (Ural) & -0.005 & $(0.026)$ & 0.020 & $(0.026)$ & $0.456 * * *$ & $(0.016)$ & $0.219 * * *$ & $(0.016)$ \\
\hline Southwest (Siberia) & $0.107 * * *$ & $(0.029)$ & $0.128 * * *$ & $(0.029)$ & $0.344 * * *$ & $(0.014)$ & $0.155 * * *$ & $(0.014)$ \\
\hline Far East & & & & & $0.550 * * *$ & $(0.019)$ & $0.060 * *$ & $(0.019)$ \\
\hline \multicolumn{9}{|l|}{$\begin{array}{l}\text { North-West (North- } \\
\text { West) omitted }\end{array}$} \\
\hline $\begin{array}{l}\text { Beijing (Moscow and } \\
\text { S Petersburg) }\end{array}$ & $0.077 * * *$ & $(0.030)$ & $0.111 * * *$ & $(0.030)$ & $0.481 * * *$ & $(0.012)$ & $0.133 * * *$ & $(0.012)$ \\
\hline $\begin{array}{l}\text { provincial capitals }(1 \\
\text { million people and } \\
\text { more) }\end{array}$ & $0.208 * * *$ & $(0.020)$ & $0.170 * * *$ & $(0.019)$ & $0.044 * * *$ & $(0.013)$ & $0.093 * * *$ & $(0.013)$ \\
\hline $\begin{array}{l}\text { prefecture level cities( } \\
500,000-999,900)\end{array}$ & $0.105^{* * *}$ & $(0.019)$ & $0.122 * * *$ & $(0.019)$ & $0.069 * * *$ & $(0.011)$ & $0.104 * * *$ & $(0.011)$ \\
\hline $100,000-499,900$ & & & & & $0,019 * *$ & $(0.009)$ & $0,034 * * *$ & $(0.009)$ \\
\hline $\begin{array}{l}\text { Cities below } \\
\text { prefecture level (with }\end{array}$ & & & & & & & & \\
\hline
\end{tabular}




\begin{tabular}{|c|c|c|c|c|c|c|c|c|}
\hline $\begin{array}{l}\text { less than } 100 \\
\text { inhabitants) } \mathrm{o}\end{array}$ & & & & & & & & \\
\hline Constant & $6.588 * * *$ & $(0.106)$ & $6.445 * * *$ & $(0.106)$ & $7.094 * * *$ & $(0.026)$ & $7.222 * * *$ & $(0.025)$ \\
\hline Observations & 14763 & & 14763 & & \multicolumn{2}{|c|}{27946} & \multicolumn{2}{|c|}{27946} \\
\hline R-squared & 0.351 & & 0.323 & & \multicolumn{2}{|c|}{0.34} & \multicolumn{2}{|c|}{0,274} \\
\hline
\end{tabular}

$* * * \mathrm{p}<0.01, * * \mathrm{p}<0.05, * \mathrm{p}<0.1$

Sources: Authors' estimates from CHIP 2002 and NOBUS 2003.

Note: For definitions of variables see Appendix 1. 


\section{Figure 1}

Employment rates among males and females aged 16 to 30 in urban China 2002 and urban Russia 2003

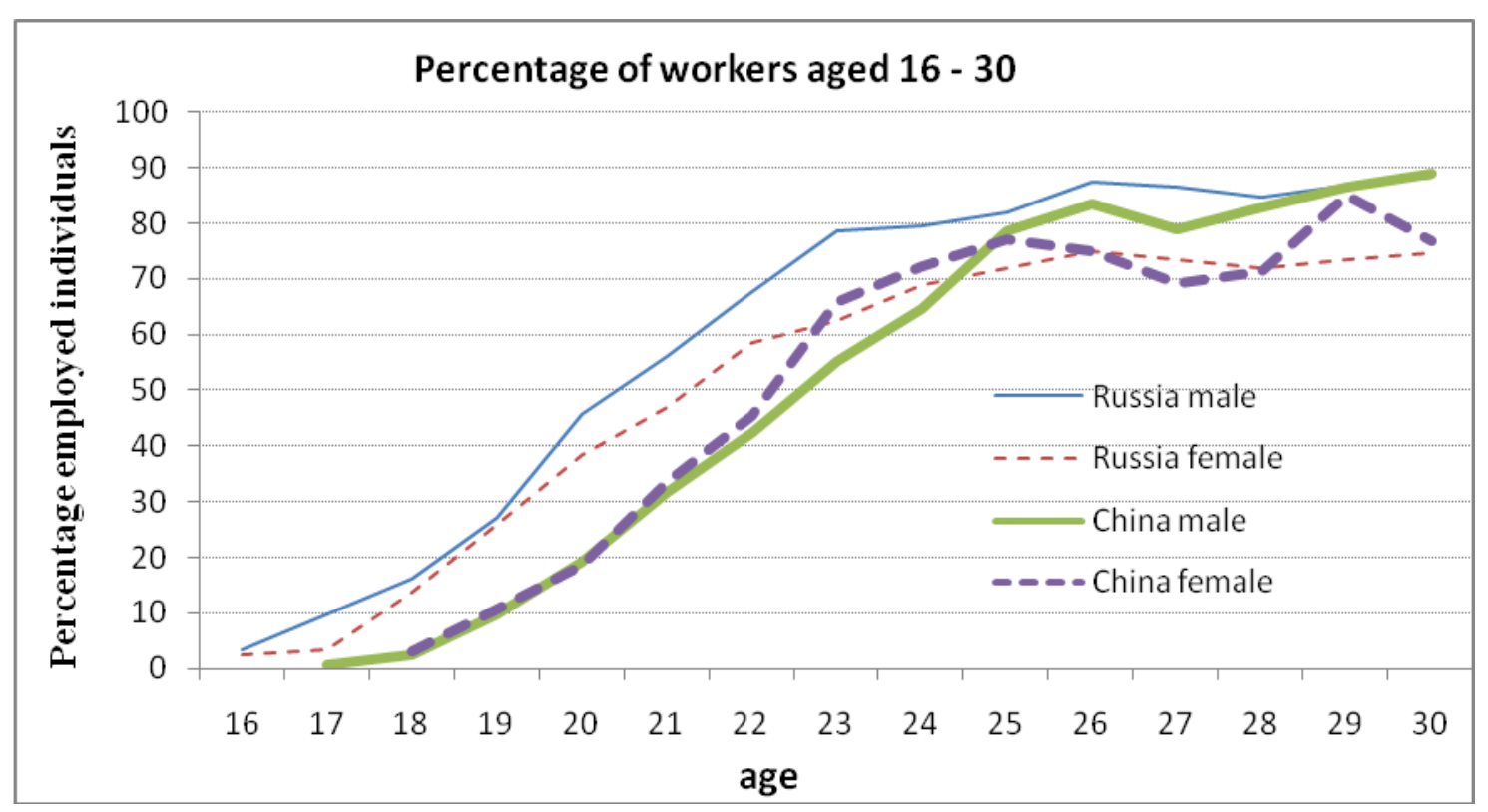

Sources: Authors' estimates from CHIP 2002 and NOBUS 2003. 


\section{Figure 2}

Employment rates among males and females aged $30+$ in urban China 2002 and urban Russia 2003

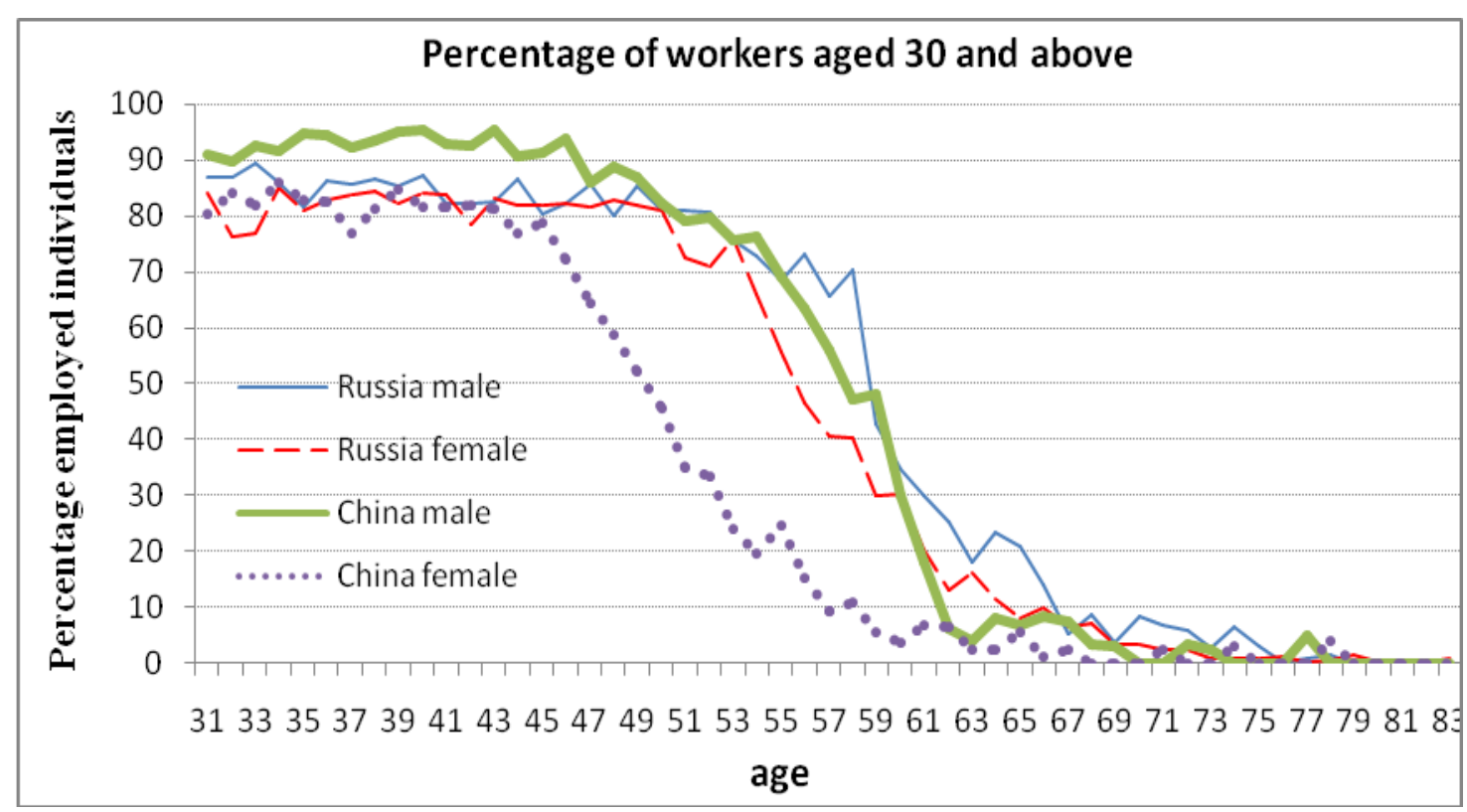

Sources: Authors' estimates from CHIP 2002 and NOBUS 2003. 


\section{Figure 3}

Coefficients for the variable Gender at different levels of the income distribution in urban China 2002 and urban Russia 2003

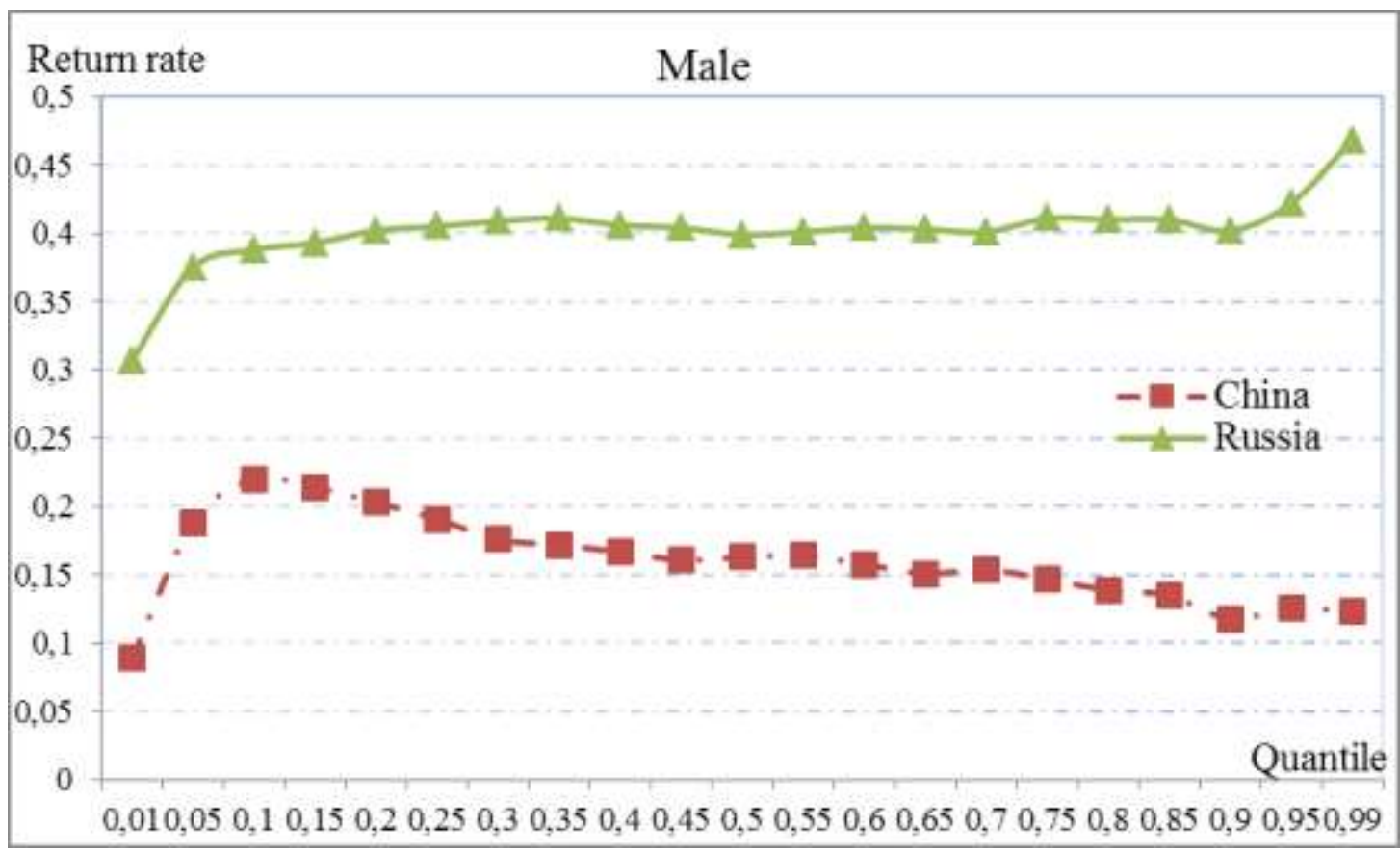

Sources: Authors' estimates from CHIP 2002 and NOBUS 2003. 


\section{Figure 4}

Coefficients for the dummy variables indicating level of education at different levels of the income distribution in urban China 2002 and urban Russia 2003

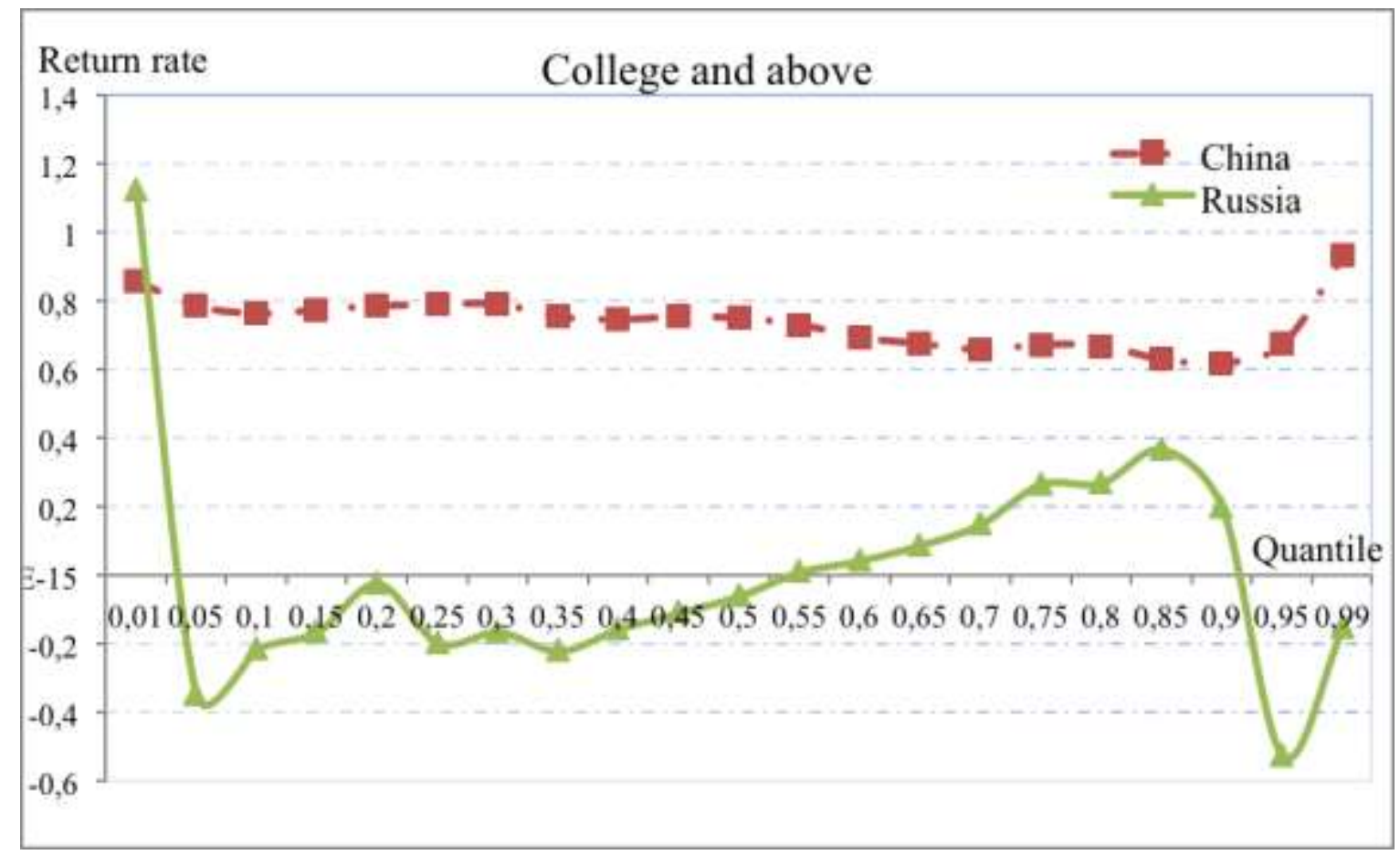



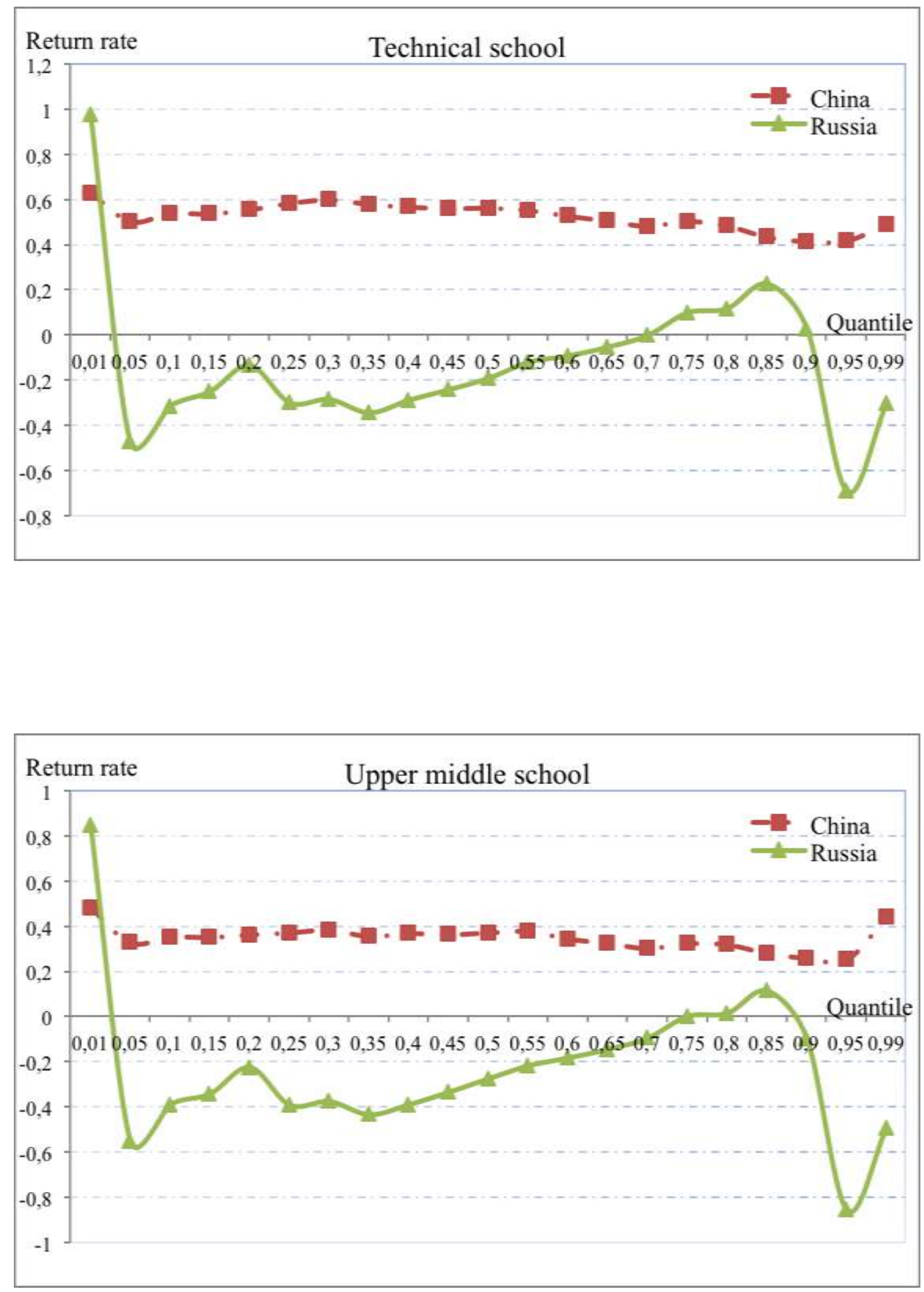


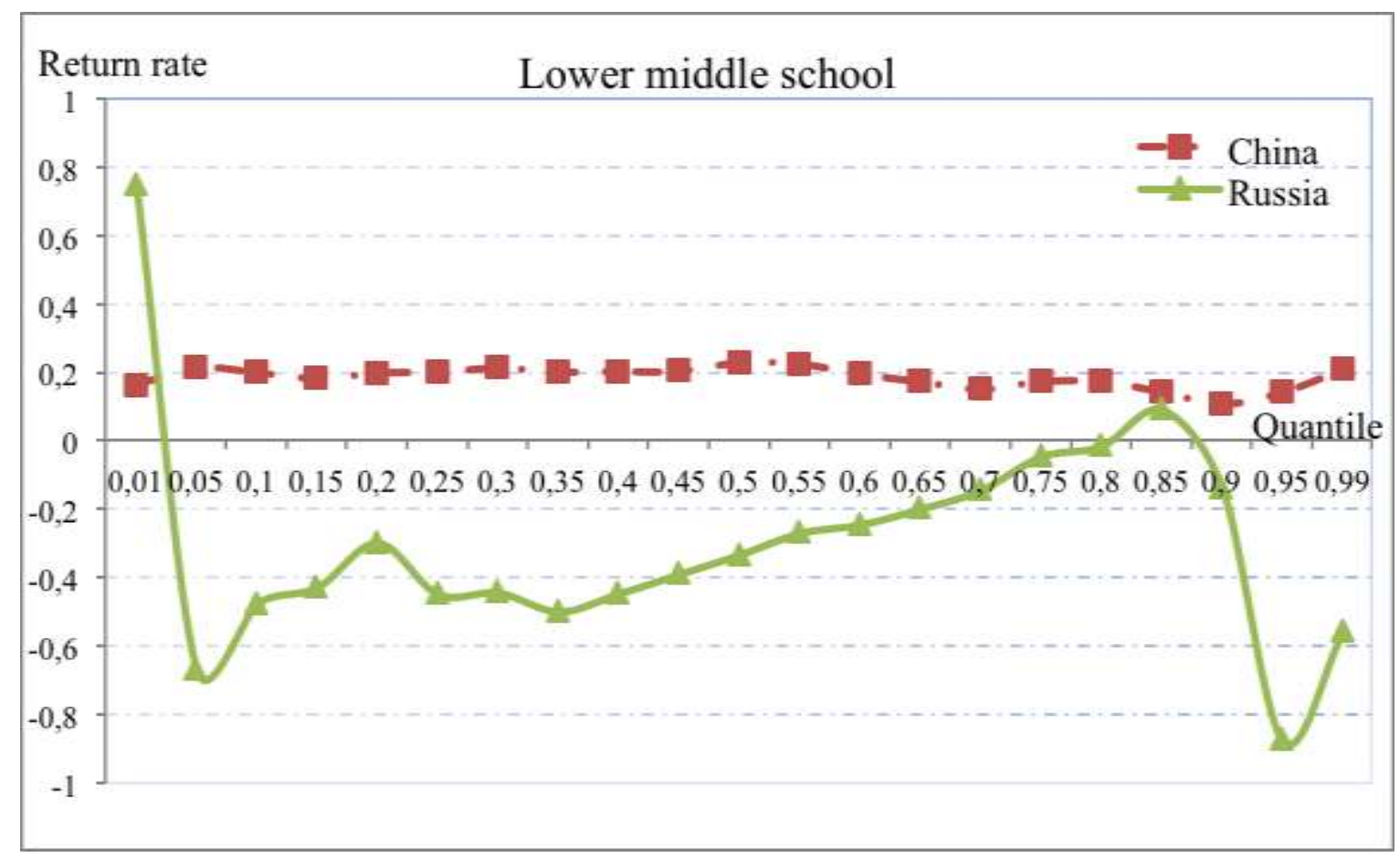

Sources: Authors' estimates from CHIP 2002 and NOBUS 2003. 
Figure 5

Coefficients for the dummy variables indicating occupation at different levels of the income distribution in urban China 2002 and urban Russia 2003

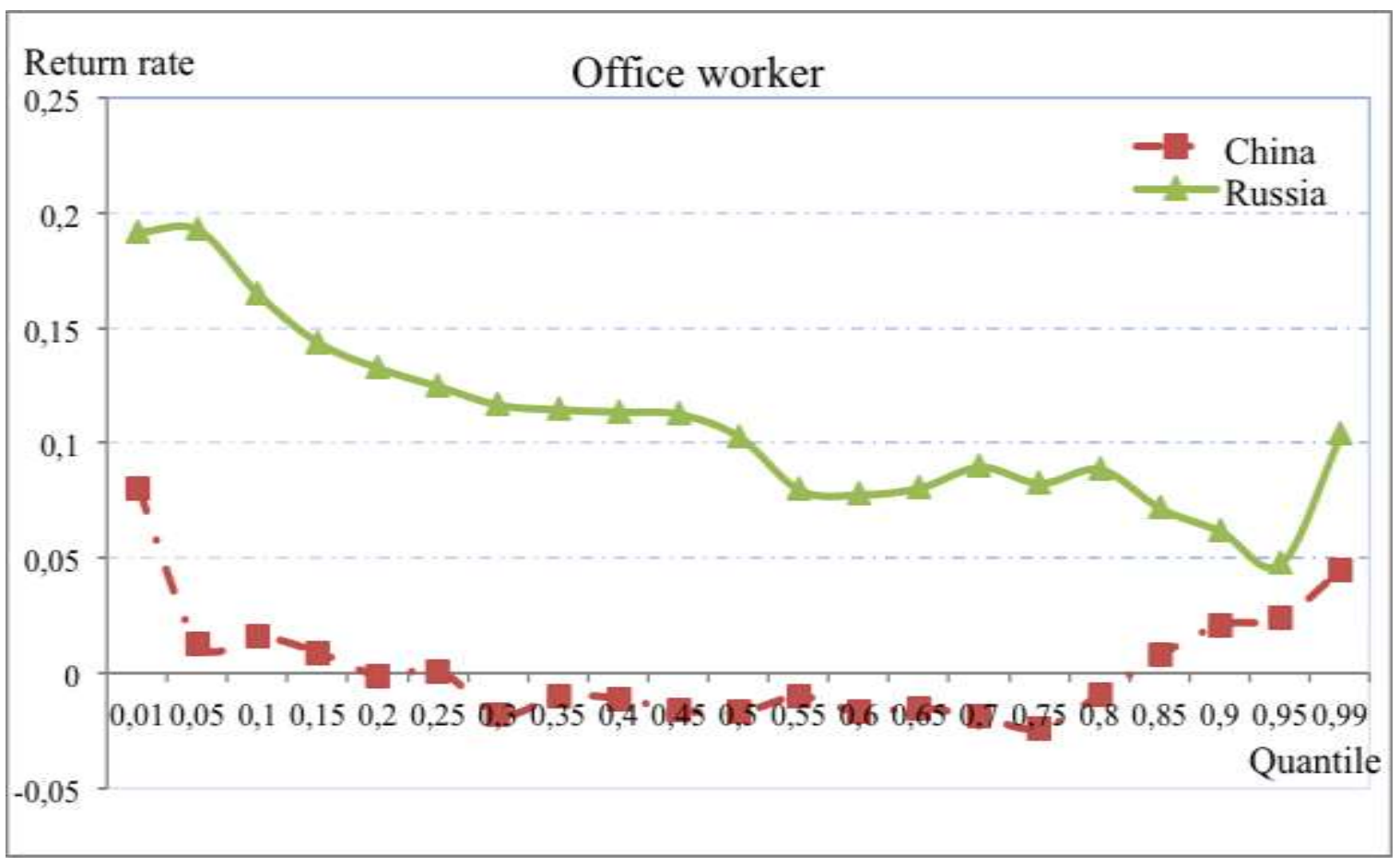



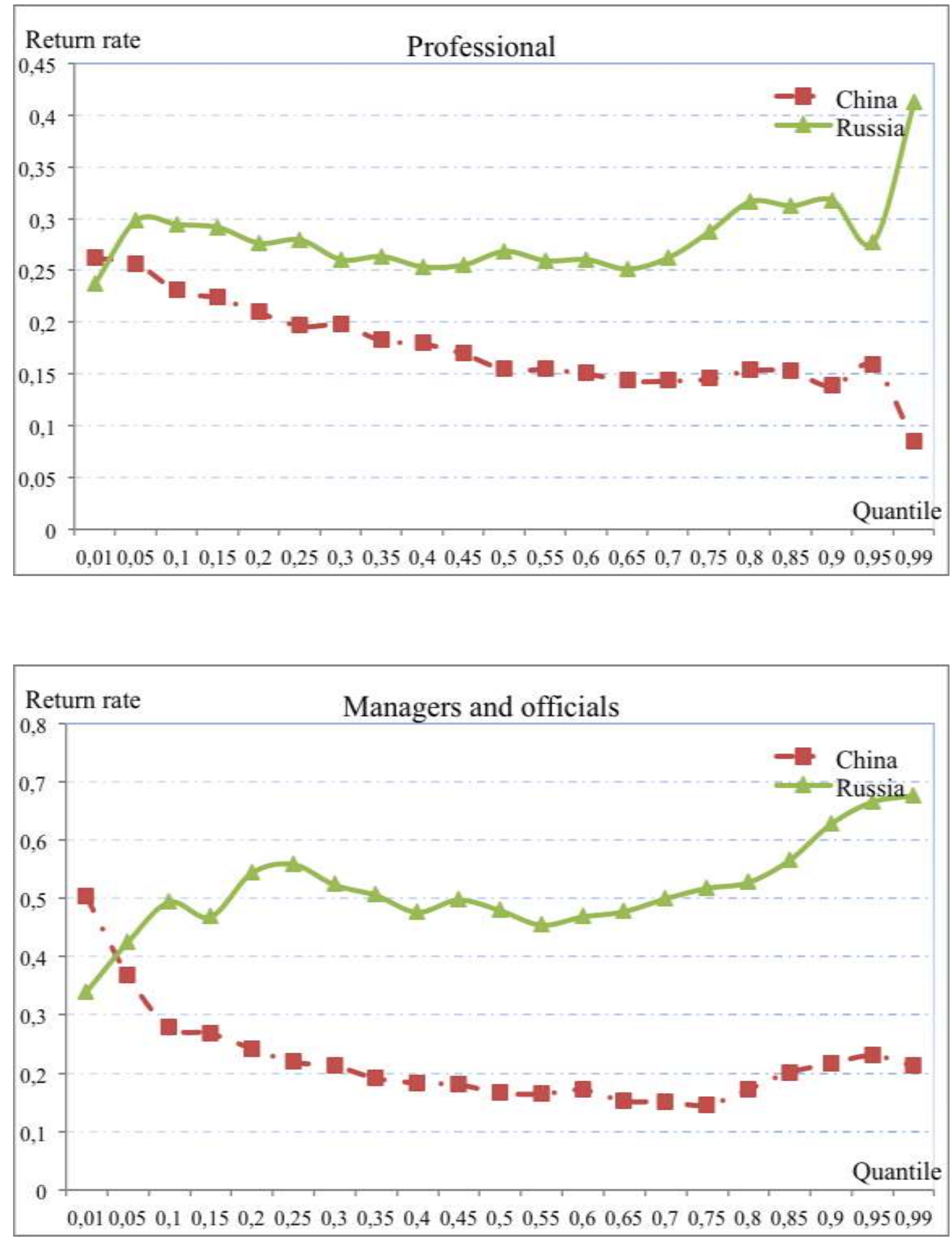

Sources: Authors' estimates from CHIP 2002 and NOBUS 2003. 


\section{Figure 6}

Coefficients for the dummy variables indicating production sector at different levels of the income distribution in urban China 2002 and urban Russia 2003
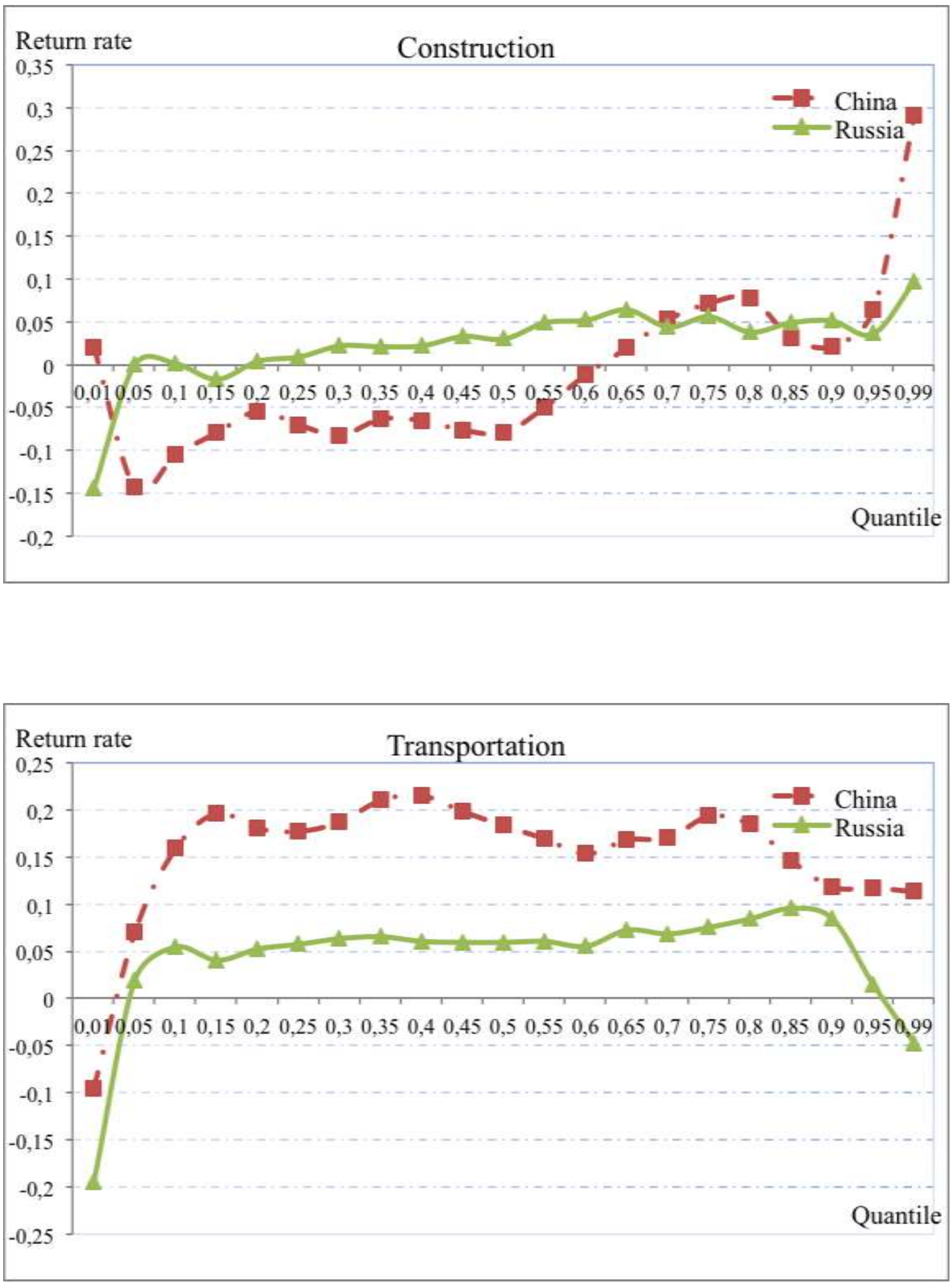

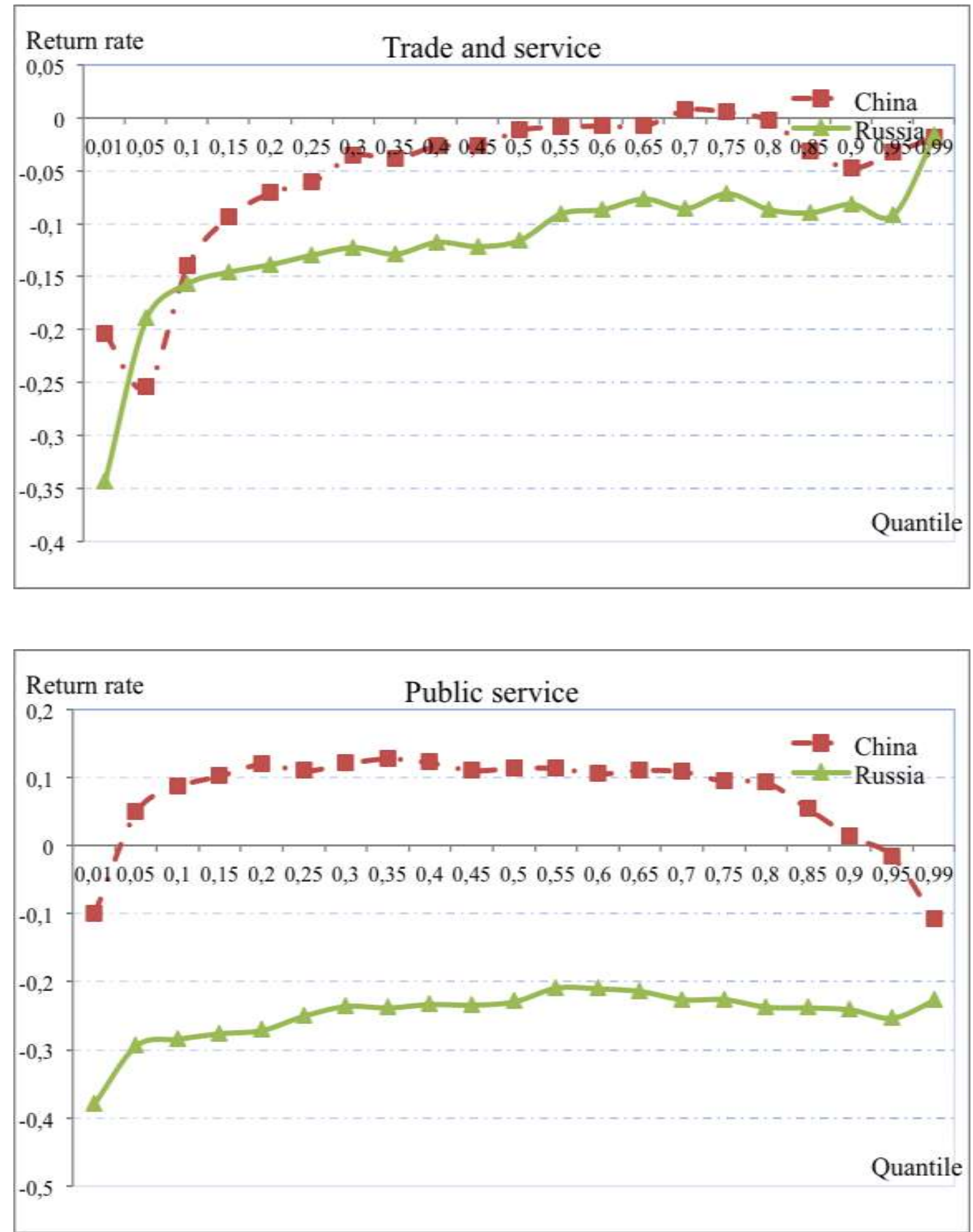


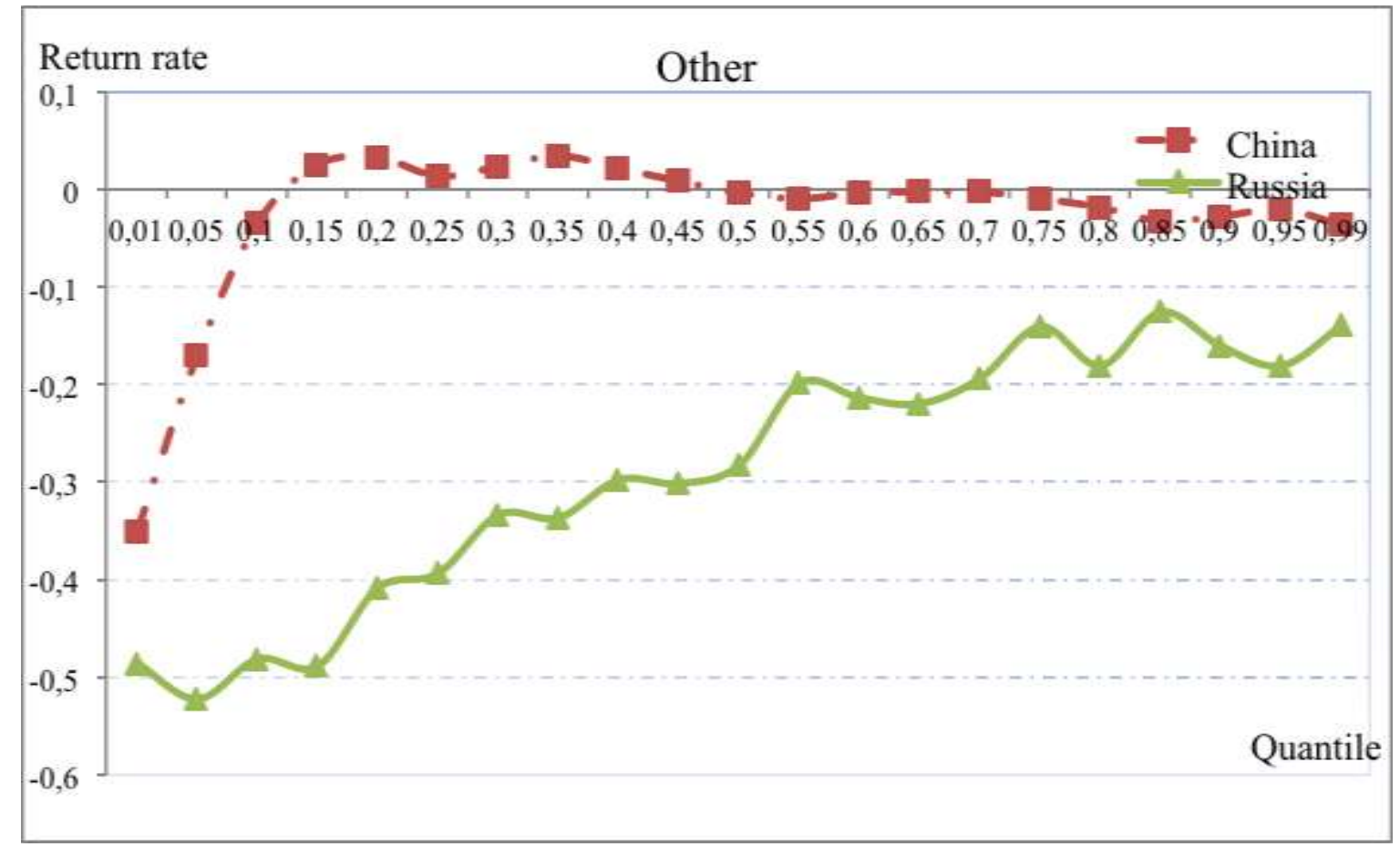

Sources: Authors' estimates from CHIP 2002 and NOBUS 2003. 


\section{Figure 7}

Coefficients for the dummy variables indicating ownership-sector at different levels of the income distribution in urban China 2002 and urban Russia 2003
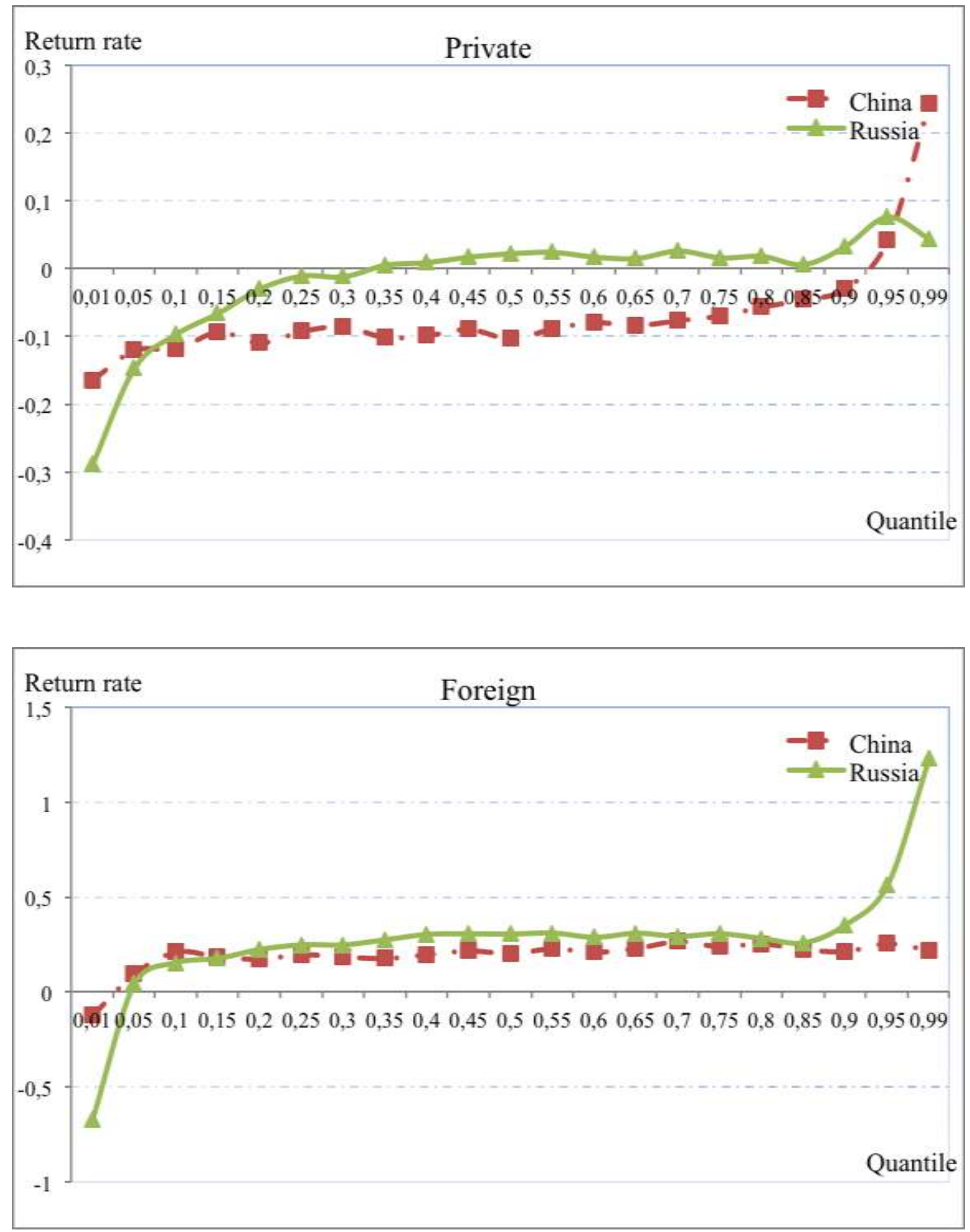


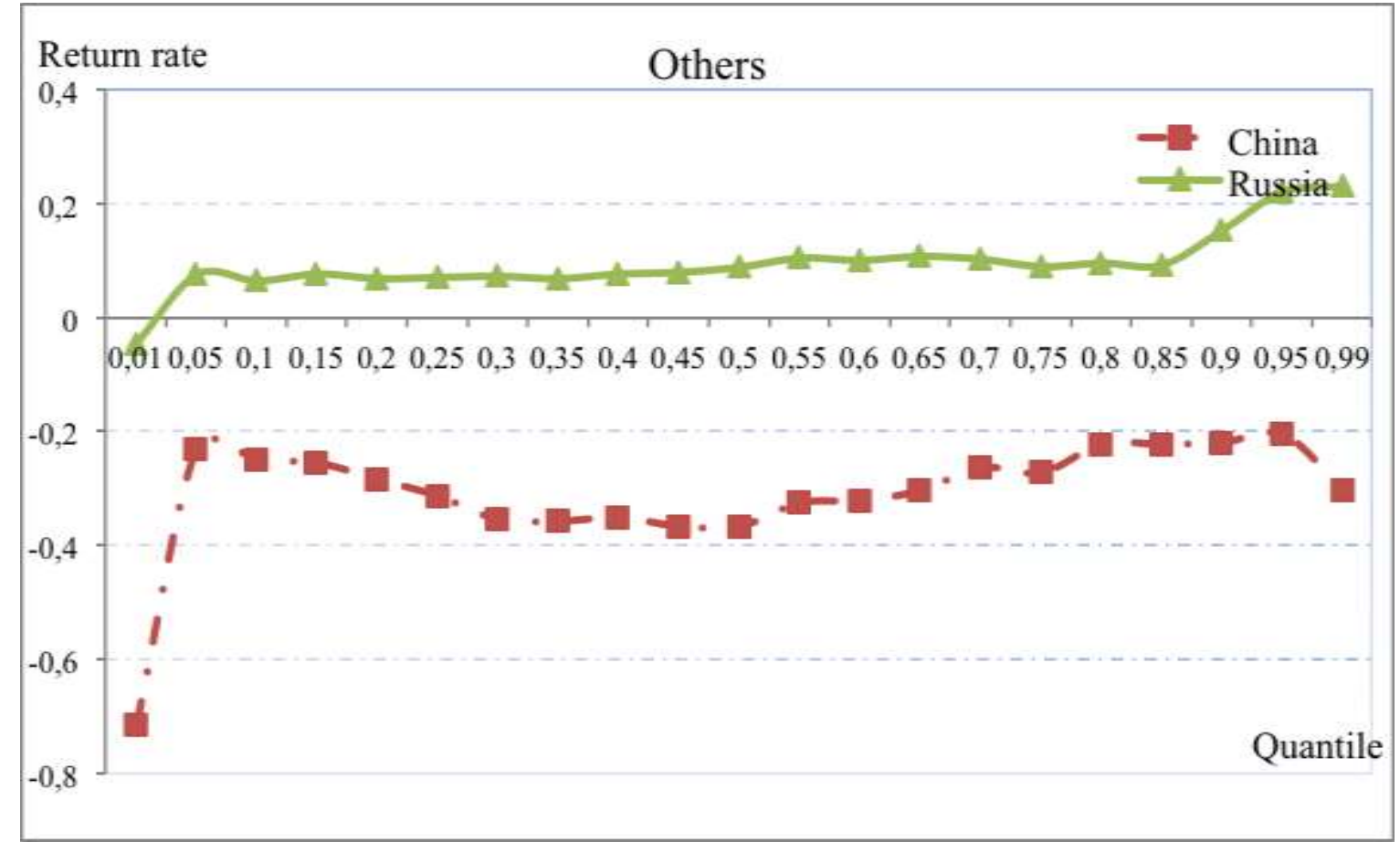

Sources: Authors' estimates from CHIP 2002 and NOBUS 2003. 


\section{Appendix 1. Variable definitions}

\begin{tabular}{|c|c|}
\hline Variables & \\
\hline Log_wage & Logarithm of monthly wage net of income tax \\
\hline Log_wage_adjust & $\begin{array}{l}\text { Logarithm of monthly wage net of income tax and adjusted for } \\
\text { regional price differences }\end{array}$ \\
\hline Gender: & \\
\hline Male & Dummy variable $($ male $=1$, others $=0$ ) \\
\hline Female & Dummy variable (female $=1$, others $=0$ ) \\
\hline Age group: & \\
\hline $16-20$ & Dummy variable (age ranges from 16 to $20=1$, others $=0$ ) \\
\hline $21-25$ & Dummy variable (age ranges from 21 to $25=1$, others $=0$ ) \\
\hline $26-30$ & Dummy variable (age ranges from 26 to $30=1$, others $=0$ ) \\
\hline $31-35$ & Dummy variable (age ranges from 31 to $35=1$, others $=0$ ) \\
\hline $36-40$ & Dummy variable (age ranges from 36 to $40=1$, others $=0$ ) \\
\hline $41-45$ & Dummy variable (age ranges from 41 to $45=1$, others $=0$ ) \\
\hline $46-50$ & Dummy variable (age ranges from 46 to $50=1$, others $=0$ ) \\
\hline $51-55$ & Dummy variable (age ranges from 51 to $55=1$,others $=0$ ) \\
\hline $56-60$ & Dummy variable (age ranges from 56 to $60=1$, others $=0$ ) \\
\hline 60 and over & Dummy variable (age is more than $60=1$, others $=0$ ) \\
\hline Education: & \\
\hline College and above & Dummy variable (completed college and above $=1$, others $=0$ ) \\
\hline Technical school & $\begin{array}{l}\text { Dummy variable (completed technical school - Dazhuan in China }=1 \text {, } \\
\text { others=0) }\end{array}$ \\
\hline Upper middle & Dummy variable (upper middle $=1$, others $=0$ ) \\
\hline Lower middle & Dummy variable (lower middle $=1$, others $=0$ ) \\
\hline Primary and below & Dummy variable ( primary and below $=1$, others $=0$ ) \\
\hline
\end{tabular}




\begin{tabular}{|c|c|}
\hline Occupation: & \\
\hline Manual worker & Dummy variable (manual worker $=1$, others $=0$ ) \\
\hline Office worker & Dummy variable (office worker $=1$, others $=0$ ) \\
\hline Professional & Dummy variable (professional $=1$, others $=0$ ) \\
\hline Manager and official & Dummy variable (manager and official $=1$, others $=0$ ) \\
\hline Economic sector: & \\
\hline Manufacturing & Dummy variable (manufacturing $=1$, others $=0$ ) \\
\hline Construction & Dummy variable (construction $=1$, others $=0$ ) \\
\hline Transportation & Dummy variable (transportation $=1$, others $=0$ ) \\
\hline Trade and service & Dummy variable (trade and service $=1$, others $=0$ ) \\
\hline Public service & Dummy variable (public service $=1$, others $=0$ ) \\
\hline Other & Dummy variable (other economic sector $=1$,others $=0$ ) \\
\hline Ownership type of firms & \\
\hline $\begin{array}{l}\text { State/sub-federal, Municipal } \\
\text { and Public association }\end{array}$ & $\begin{array}{l}\text { Dummy variable (state/sub-federal, municipal and public association } \\
=1 \text {, others }=0 \text { ) }\end{array}$ \\
\hline Private & Dummy variable (private $=1$, others $=0$ ) \\
\hline $\begin{array}{l}\text { Foreign ownership and } \\
\text { mixed with both domestic } \\
\text { and foreign ownership }\end{array}$ & $\begin{array}{l}\text { Dummy variable (foreign ownership and mixed with both domestic } \\
\text { and foreign ownership }=1 \text {, others }=0 \text { ) }\end{array}$ \\
\hline Others / No answer & Dummy variable (others or no answer $=1$, others $=0$ ) \\
\hline $\begin{array}{l}\text { Settlements Russia } \\
\text { (China) }\end{array}$ & \\
\hline $\begin{array}{l}\text { Moscow and S Petersburg } \\
\text { (Municipalities) }\end{array}$ & $\begin{array}{l}\text { Dummy variable (Moscow and S Petersburg in Russia is defined as } 1 \text {, } \\
\text { while the Municipalities in China is defined as } 1 \text {,others }=0 \text { ) }\end{array}$ \\
\hline $\begin{array}{l}1 \text { million people and more } \\
\text { (Province capital) }\end{array}$ & $\begin{array}{l}\text { Dummy variable ( } 1 \text { million people and more in Russia is defined as } \\
1 \text {, while the province capital in China is defined as } 1 \text {, others }=0 \text { ) }\end{array}$ \\
\hline $\begin{array}{l}500,000-999,900 \\
\text { (Other cities) }\end{array}$ & $\begin{array}{l}\text { Dummy variable }(500,000-999,900 \text { in Russia is defined as } 1 \text {, while } \\
\text { other cities in China is defined as } 1 \text {, others }=0)\end{array}$ \\
\hline
\end{tabular}




\begin{tabular}{|c|c|}
\hline $20,000-499,900$ & Dummy variable $(20,000-499,900$ in Russia is defined as 1 , others $=0)$ \\
\hline $\begin{array}{l}\text { Federal districts } \\
\text { Russia (China) }\end{array}$ & \\
\hline The Central(Central) & $\begin{array}{l}\text { Dummy variable (The Central part in Russina and China=1, } \\
\text { others=0) }\end{array}$ \\
\hline The Northwest ( Northwest) & $\begin{array}{l}\text { Dummy variable (The Northwest part of Russia and China=1, } \\
\text { others=0) }\end{array}$ \\
\hline The South (Southwest) & Dummy variable (The Southwest of Russia and China $=1$, others $=0$ ) \\
\hline $\begin{array}{l}\text { Privozhsky(Volga) } \\
\text { ( Coastal) }\end{array}$ & $\begin{array}{l}\text { Dummy variable (The Privozhsky(Volga) in Russia and the Costal in } \\
\text { China=1, others=0) }\end{array}$ \\
\hline $\begin{array}{l}\text { The Urals } \\
\text { (Municipality) }\end{array}$ & $\begin{array}{l}\text { Dummy variable (The Urals in Russia and the Municipalities in } \\
\text { China }=1 \text {, others }=0 \text { ) }\end{array}$ \\
\hline The Siberian & Dummy variable (The Siberian in Russia $=1$, others $=0$ ) \\
\hline $\begin{array}{l}\text { The Far East } \\
\text { (Northeast) }\end{array}$ & $\begin{array}{l}\text { Dummy variable (The Far East in Russia and Northeast in China=1, } \\
\text { others=0) }\end{array}$ \\
\hline
\end{tabular}

